\title{
BIOLOGICAL RESPONSES OF BRUSHITE-FORMING Zn- AND ZnSr- SUBSTITUTED $\beta$-TRICALCIUM PHOSPHATE BONE CEMENTS
}

\author{
S. Pina ${ }^{1 a *}$, S.I. Vieira ${ }^{2 a}$, P. Rego ${ }^{3}$, P.M.C. Torres ${ }^{1}$, O.A.B. da Cruz e Silva ${ }^{2}$, E.F. da Cruz e Silva ${ }^{4}$, and J.M.F. Ferreira ${ }^{1}$ \\ ${ }^{1}$ University of Aveiro, Dept. of Ceramics and Glass Engineering, CICECO, 3810-193 Aveiro, Portugal. \\ ${ }^{2}$ University of Aveiro, Health Sciences Dept., Centro de Biologia Celular, 3810-193 Aveiro, Portugal. \\ ${ }^{3}$ University of Lisbon, Orthopaedic Clinic, Medicine Faculty, 1600-190 Lisbon, Portugal. \\ ${ }^{4}$ University of Aveiro, Dept. of Biology, Centro de Biologia Celular, 3810-193 Aveiro, Portugal
}

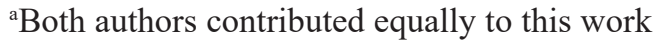

\begin{abstract}
The core aim of this study was to investigate zinc ( $\mathrm{Zn})$ and zinc and strontium ( $\mathrm{ZnSr}$ )-containing brushite-forming $\beta$-tricalcium phosphate (TCP) cements for their effects on proliferation and differentiation of osteoblastic-like cells (MC3T3-E1 cell line) as well as for their in vivo behaviour in trabecular bone cylindrical defects in a pilot study. In vitro proliferation and maturation responses of MC3T3E1 osteoblastic-like cells to bone cements were studied at the cellular and molecular levels. The $\mathrm{Zn}$ - and Sr-containing brushite cements were found to stimulate pre-osteoblastic proliferation and osteoblastic maturation. Indeed, MC3T3E1 cells exposed to the powdered cements had increased proliferative rates and higher adhesiveness capacity, in comparison to control cells. Furthermore, they exhibited higher alkaline phosphatase (ALP) activity and increased Type-I collagen secretion and fibre deposition into the extracellular matrix. Proliferative and collagen deposition properties were more evident for cells grown in cements doped with Sr. The in vivo osteoconductive properties of the $\mathrm{ZnCPC}$ and $\mathrm{ZnSrCPC}$ cements were also pursued. Histological and histomorphometric analyses were performed at 1 and 2 months after implantation, using carbonated apatite cement (Norian $\mathrm{SRS}^{\circledR}$ ) as control. There was no evidence of cement-induced adverse foreign body reactions, and furthermore $\mathrm{ZnCPC}$ and $\mathrm{ZnSrCPC}$ cements revealed better in vivo performance in comparison to the control apatite cement. Additionally, the presence of both zinc and strontium resulted in the highest rate of new bone formation. These novel results indicate that the investigated $\mathrm{ZnCPC}$ and $\mathrm{ZnSrCPC}$ cements are both biocompatible and osteoconductive, being good candidate materials to use as bone substitutes.
\end{abstract}

Key words: Zinc, strontium, brushite cement, osteoblast proliferation, alkaline phosphatase, MC3T3-E1 cell adhesion, Type-I collagen, trabecular bone regeneration.

*Address for correspondence:

S. Pina

Dept. of Ceramics and Glass Engineering,

University of Aveiro, CICECO,

3810-193 Aveiro, Portugal

E-mail: sandra.pina@ua.pt

\section{Introduction}

Calcium phosphate cements (CPC) have unique characteristics for bone substitution compared with other biomaterials. Their excellence is due to good biocompatibility, excellent bioactivity, self-setting characteristics, low setting temperature, adequate stiffness, and easy shaping for any complicated geometry (Brown and Chow, 1983; Yuan et al., 2000; Baroud et al., 2005; Bohner and Baroud, 2005; Gauthier et al., 2005; Boesel and Reis, 2006; Wang et al., 2006; Alves et al., 2008; Burguera et al., 2008). In addition, CPC have such compositional resemblance to bone mineral that they induce a biological response similar to the one generated during bone remodelling.

Among the different biocompatible calcium phosphate $(\mathrm{CaP})$ phases present in human bone, brushite (dicalcium phosphate dihydrate, DCPD) has a higher solubility than hydroxyapatite (HA) at physiological $\mathrm{pH}$, and an ideal in vivo resorption rate (Constantz et al., 1998; Bohner et al., 2003; Gisep et al., 2003). Brushite-based bone cements are generally well tolerated by the bone and soft tissue environment in vivo, such that cement resorption is closely followed by new bone formation. Furthermore, brushite cements are known to be biocompatible, osteoconductive and bioresorbable, having a potential interest for bone regeneration procedures.

From a cellular and molecular perspective, it has been shown that some biomaterials are able to directly modify the osteoblastic proliferation rate and some of their functions, such as the synthesis of alkaline phosphatase (ALP) (Naji and Harmand, 1991; Malik et al., 1992; Puleo et al., 1993). The ionic composition of such biomaterials is a key factor in their bioactivity (Ito et al., 2002; Li et al., 2008; Pina et al., 2010a). Zn and Sr incorporated into tricalcium phosphate (TCP) have a direct specific proliferative effect on osteoblastic cells in vitro and a selective inhibitory effect on osteoclastic bone resorption in vivo (Ito et al., 2000; Otsuka et al., 2000; Ito et al., 2002; Li et al., 2008). Moreover, $\mathrm{Zn}$ is involved in many metallo-enzymes and proteins, including ALP, whereas $\mathrm{Sr}$ enhances collagen synthesis and has beneficial effects in the treatment of osteoporosis, due to the prevention of bone loss by a mechanism that depresses bone resorption (McComb et al., 1979; Rokita et al., 1993; Dahl et al., 2001; Marie et al., 2001).

Among various calcium phosphate phases $\beta$-TCP is greatly biocompatible and resorbable. Furthermore, $\beta$ - 
TCP is an adequate carrier for doping ions such as $\mathrm{Sr}$ and $\mathrm{Zn}$ that might be released at low rates. Ito et al. (Ito et al., 2000) found that a slow $\mathrm{Zn}^{2+}$ release from a biphasic $\mathrm{ZnTCP} / \mathrm{AP}$ ceramics containing $\mathrm{Zn}$ doped $\beta$-TCP implanted in rabbit femora stimulated bone formation. Based on a histological and histomorphometrical study using femora of rabbits, Kawamura et al. (Kawamura et al., 2000) reported that $51 \%$ of new bone has grown around ZnTCP/AP implants.

Osteoblasts are cells found on bone surfaces, and are directly responsible for bone formation. As osteoblasts differentiate from their precursors and alter their morphology and expression and/or activity of functional markers (maturation process), they begin to secrete bone matrix proteins such as Type-I collagen that represents about $90 \%$ of the organic matrix. The network of Type-I collagen fibres provides the structure on which bone mineral is deposited. Type-I collagen and endogenous brushite particles are both predominant in fracture callus (Lenart et al., 1972; Kurdy et al., 1998), with the main structural framework of a human fracture callus consisting of disordered, mineralized collagen fibrils containing $\mathrm{CaP}$ crystals. Brushite particles are found in the noncollagenous organic matter around nonmineralized, ordered collagen fibrils, and it is believed that these particles serve as the reservoir of calcium and phosphate ions for subsequent mineralization (Wen et al., 1995).

The in vivo osteoconductive relevance of brushite cements has been well documented but the knowledge concerning the in vivo behaviour of brushite-forming cements with $\mathrm{Zn}$ and $\mathrm{Sr}$ co-substituted in $\beta$-TCP is still limited. The aim of the present study was to examine the osteoconductive properties of two new brushite-forming $\mathrm{Zn}$ and $\mathrm{ZnSr}$-containing CPCs, previously studied by us (Pina et al., 2010b). The in vitro proliferation and differentiation responses of MC3T3-E1 osteoblast-like cells to the bone cements were initially studied. Various cellular and molecular responses to the biomaterials were assayed, including cell viability determinations by the resazurin assay, photometric evaluation of ALP activity after enzymatic cleavage of p-nitrophenyl phosphate, and time-dependent Type-I collagen production. The in vivo osteoconductive properties of these bone cements were further assayed after implantation in trabecular bone in pigs, and compared to a commercial apatite CPC.

\section{Materials and Methods}

\section{Cement preparation}

Brushite cements were prepared as described in the previous study (Pina et al., 2010b). Briefly, the cement pastes were prepared by mixing $55 \mathrm{wt} . \%$ of $\mathrm{Zn}$ - or $\mathrm{ZnSr}$ substituted $\beta$-tricalcium phosphate $(\beta$-TCP) powder with 45 wt.\% of monocalcium phosphate monohydrate (MCPM, Sigma-Aldrich, Munich, Germany) using liquidto-powder ratio (LPR) of $0.34 \mathrm{~mL} \mathrm{~g}^{-1}$. The aqueous solution used was 10 wt.\% poly(ethylene glycol) (PEG) (200, Sigma-Aldrich) +15 wt. $\%$ citric acid solution.

$\mathrm{Zn}$ - and $\mathrm{ZnSr}$-substituted $\beta$-TCP powders were synthesized by aqueous precipitation as described in detail in previous reports (Kannan et al., 2006; Kannan et al., 2008; Kannan et al., 2009). The precipitates were vacuum filtrated, dried at $110^{\circ} \mathrm{C}$, heat treated for $2 \mathrm{~h}$ at $1100^{\circ} \mathrm{C}$ and grounded under dry conditions in a planetary mill, and finally passed through a sieve with a mesh size of $36 \mu \mathrm{m}$. The starting powders were constituted by: $2.4 \pm 0.1 \mathrm{~mol} . \%$ $\mathrm{Zn}^{2+}$ for $\mathrm{ZnCPC}$, and $2.3 \pm 0.2 \mathrm{~mol} \% \mathrm{Zn}^{2+}$ and $2.1 \pm 0.1$ mol.\% $\mathrm{Sr}^{2+}$ for $\mathrm{ZnSrCPC}$, determined by ICP spectroscopy in a previous work by the same authors (Pina et al., 2010b). The $\mathrm{Zn}$ - and $\mathrm{ZnSr}$-substituted $\beta$-TCP cements were designated as $\mathrm{ZnCPC}$ and $\mathrm{ZnSrCPC}$, respectively.

\section{MC3T3-E1 cell culture}

The osteoblastic cell line MC3T3-E1 (ATCC, Barcelona, Spain; CRL-2593) was established from C57BL/6 mouse calvaria and selected on the basis of high ALP activity in the resting state. $\mathrm{MC} 3 \mathrm{~T} 3-\mathrm{E} 1$ cells were maintained at $37^{\circ} \mathrm{C}$ in a humidified atmosphere of $5 \% \mathrm{CO}_{2}$ in air, in $2 \mathrm{mM}$ Glutamine-containing Minimum Essential $\alpha$-Medium in EBSS (Eagle's Balanced Salt Solution) supplemented with $10 \%(\mathrm{v} / \mathrm{v})$ foetal bovine serum (FBS), $1 \%(\mathrm{v} / \mathrm{v})$ of a 100 $\mathrm{U} \mathrm{mL}^{-1}$ penicillin and $100 \mathrm{mg} \mathrm{mL}^{-1}$ streptomycin solution (Gibco BRL, Invitrogen, Life Technologies, Carlsbad, CA, USA) and $3.7 \mathrm{~g} \mathrm{~L}^{-1} \mathrm{NaHCO}_{3}$. Sub-confluent cultures (80$90 \%$ confluency) were split $1: 5$ using a $0.25 \%$ trypsin/ EDTA (Gibco BRL, Invitrogen) solution at $5 \% \mathrm{CO}_{2}, 37^{\circ} \mathrm{C}$.

\section{Cytotoxicity and cell proliferation assays in cements}

The resazurin metabolic assay (Ueno et al., 2006; Pina et al., 2010b) was used to determine the cements' cytotoxicity/biocompatibility to MC3T3-E1 cells. The sensitivity and the range of linearity between resazurin reduction to resorufin and the density of MC3T3-E1 viable cells were first determined in a cell curve assay, as described previously (Pina et al., 2010b) (Fig. 1). Briefly, cells were seeded in $35 \mathrm{~mm}$ plates at $1 \times 10^{3}$ cells $\mathrm{cm}^{-2}$ and, at the indicated time points, cells were incubated for $4 \mathrm{~h}$ with fresh medium containing $10 \%$ of a resazurin (Sigma-Aldrich) solution $\left(0.1 \mathrm{mg} \mathrm{mL}^{-1}\right.$ resazurin in phosphate buffer saline (PBS) [Pierce, Perbio, Thermo Scientific, Bonn, Germany]). Resazurin reduction was

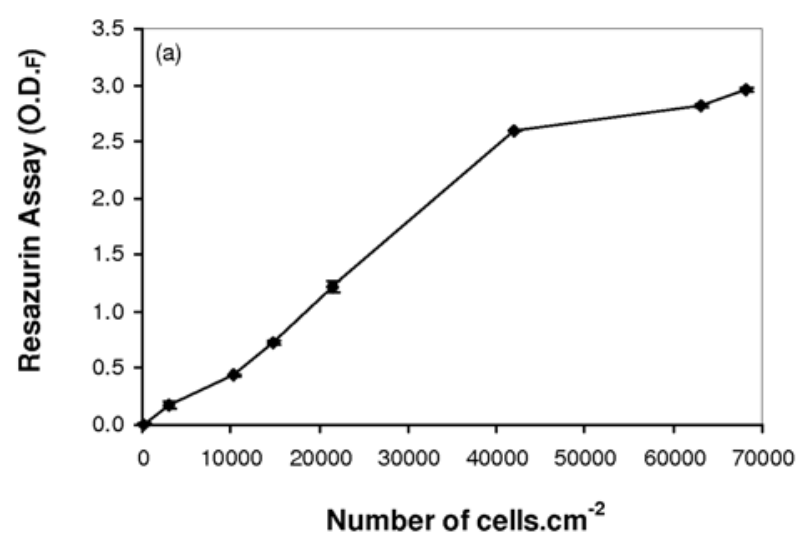

Fig. 1. Growth curve of MC3T3-E1, carried out using the resazurin assay, was carried out in order to determine the zone of linearity between resazurin assay O.D. and cell density. 
thereafter measured spectrophotometrically (Cary 50 BIO, Varian, Palo Alto, CA, USA) at 570 and $600 \mathrm{~nm}$. The number of viable cells was further counted using a $0.4 \%$ solution of the Trypan blue dye (Sigma-Aldrich) and a haemocytometer. For each day, a final resazurin value (O.D. ${ }_{\mathrm{F}}$ ) was calculated as the ratio O.D. 570/O.D. $600 \mathrm{~nm}$ minus the O.D. 570/O.D. $600 \mathrm{~nm}$ ratio of a negative control (resazurin media incubated for $4 \mathrm{~h}$ in the absence of cells), and the O.D. ${ }_{F}$ was plotted against cell density.

To determine dose-dependent cell viability and proliferation when exposed to the powdered cements milled up to an average particle size of about $15 \mu \mathrm{m} .1 \times 10^{5}$ cells were seeded in $35 \mathrm{~mm}$ wells (density of $1 \times 10^{4}$ cells $\mathrm{cm}^{-2}$ ), and cultured in cell media supplemented with $0,0.01,0.1$ or $1 \mathrm{mg} \mathrm{mL}^{-1}$ of $\mathrm{ZnCPC}$ or $\mathrm{ZnSrCPC}$ cement powders. This range of cement concentrations was chosen as $1 \mathrm{mg}$ $\mathrm{mL}^{-1}$ already resulted in saturated solutions. Of note, prior to cell experiments, cement samples were sterilized by $\gamma$ radiation. Following 24,48 and $72 \mathrm{~h}$ of incubation at $37^{\circ} \mathrm{C}$ in a humidified $5 \% \mathrm{CO}_{2}$ and $95 \%$ air atmosphere, growth medium was removed by aspiration and replaced with fresh medium containing $10 \%$ of the $0.1 \mathrm{mg} \mathrm{mL}^{-1}$ resazurin solution. After $4 \mathrm{~h}$ of incubation, $1 \mathrm{~mL}$ of the medium was collected and cell viability determined by measuring O.D. at 570 and $600 \mathrm{~nm}$, as described above. For each time point, the O.D. ${ }_{\mathrm{F}}$ levels of cells incubated with $0 \mathrm{mg} \mathrm{mL}^{-1}$ cement powder were taken as $100 \%$ and cell viability calculated as a percentage of these control values. All experiments were carried out in triplicate and expressed as the mean \pm standard error of the mean. Upon $72 \mathrm{~h}$, cells morphology was evaluated by phase contrast $(\mathrm{PhC})$ microscopy in an inverted Olympus (Hamburg, Germany) IX81 epifluorescence microscope, and microphotographs were taken at $18^{\circ} \mathrm{C}$ with a Digital CCD monochrome camera FView II (Olympus Soft Imaging System).

\section{Determination of alkaline phosphatase activity}

MC3T3-E1 cells were seeded at $1 \times 10^{4}$ cells $\mathrm{cm}^{-2}$ in 35 mm wells and cultured on $1 \mathrm{mg} \mathrm{mL}^{-1} \mathrm{ZnCPC}$ and $\mathrm{ZnSrCPC}$ powders. At day 3 in culture, achievement of cell confluency was visually confirmed. Alkaline phosphatase (ALP) activity of exposed cells was evaluated at 0, 1, 3, 6, 14 and 21 days post-confluency (DPC). After removal of the culture medium, cells were washed with PBS and harvested in $1 \mathrm{~mL}$ universal ALP buffer $(100 \mathrm{mM}$ citric acid, $100 \mathrm{mM} \mathrm{KH}_{2} \mathrm{PO}_{4}, 100 \mathrm{mM}$ sodium tetraborate. $10 \mathrm{H}_{2} \mathrm{O}, 100 \mathrm{mM}$ Tris, $100 \mathrm{mM} \mathrm{KCl}$; $\mathrm{pH}$ 11) with a disposable cell scraper. Cells with or without cement were sonicated twice for $20 \mathrm{sec}$ and centrifuged for $5 \mathrm{~min}$ at $2000 \mathrm{rpm}$ at room temperature. ALP activity in the supernatant was determined following addition of the $\mathrm{p}$ nitrophenyl phosphate substrate (Fluka, Buchs, Switzerland). The production of p-nitrophenol was determined spectrophotometrically at $420 \mathrm{~nm}$, after 2 and 5 min of reaction at $37^{\circ} \mathrm{C}$. The ALP activity was expressed as the increase in p-nitrophenol aborbance per min per microgram of protein $\left(\Delta \mathrm{OD} \cdot \mathrm{min}^{-1} \cdot \mathrm{mg}^{-1}\right)$, upon subtraction of the blank O.D. (1 mL universal buffer plus substrate). To determine protein mass, parallel samples were harvested with $1 \%$ SDS, and total protein content measured using a BCA kit (Pierce).

\section{ZnCPC and ZnSrCPC time-dependent cell adhesion} assays

The capacity of cells to adhere to a plastic support was measured upon cell exposure to the cement powders for increasing time periods. Post-exposure adhesion assays were performed at $0,3,14$ and 21 days post-confluency (DPC), upon cell plating as described above for the ALP assay (day $0=3$ days post-seeding). Cell media was changed every other $\sim 3-5$ days in culture. At each experimental day, cells were washed with PBS, incubated with Trypsin-EDTA solution for $5 \mathrm{~min}$ at $37^{\circ} \mathrm{C}$, and resuspended in $3 \mathrm{~mL}$ fresh media. Cells were counted using the Trypan blue dye; 1 × $10^{5}$ cells were seeded into 24 well plates with $1 \mathrm{~mL}$ fresh media (final volume) and left to adhere for $1 \mathrm{~h}$ in an atmosphere of $5 \% \mathrm{CO}_{2}$ at $37^{\circ} \mathrm{C}$. Quantification of adherent cells was performed indirectly by scoring the number of non-adherent resuspended cells in the media. Thus, cell media were collected and an aliquot applied to a haemocytometer. Resuspended cells were counted using the Trypan blue dye and the number of viable non-adherent cells determined. Consequently, the percentage of adherent cells was calculated, taking as $100 \%$ the 1 × $10^{5}$ cells seeded. Three independent experiments were performed.

\section{Type-I collagen time-dependent protein expression and cellular localization}

MC3T3-E1 cells were treated as described for the ALP assays and subjected to immunoblot analyses to determine the profile of Type-I procollagen and collagen protein expression, and secretion into the medium, with time of exposure to $1 \mathrm{mg} / \mathrm{ml}$ cement powders for various DPC (confluency achieved at 3 days in vitro). Type-I collagen cellular distribution was further analyzed by immunocytochemistry procedures at 3 DPC.

\section{Antibodies}

The primary antibody used was anti-Collagen Type-I (Novus Biologicals, Cambridge, UK), which recognizes Type-I procollagen (monomeric $\alpha 1$ (I) and $\alpha 2$ (I) chains, $\beta$ chains corresponding to $\alpha / \alpha$ dimmers, and trimeric $\gamma$ chains), and various collagen forms (tropocollagen, the mature trimeric $\gamma$ chains, microfibrils, fibrils and fibres F(I)). Secondary antibodies used were FITC-conjugated anti-rabbit IgGs (Calbiochem, Merck4Biosciences, Nottingham, UK) for immunocytochemistry analyses, and horseradish peroxidase-linked anti-rabbit IgGs for enhanced chemiluminescence (ECL) detection (GE Healthcare, Chalfont St. Giles, UK).

\section{Immunoblot analyses of Type-I collagen protein expression and media secretion}

At the indicated days in post-confluency cultures, cells conditioned media ( $1 \mathrm{~mL}$ ) were collected into $10 \%$ SDScontaining microtubes, cells were washed with PBS and harvested with a $1 \%$ SDS boiling solution. Samples were boiled for $10 \mathrm{~min}$, subjected to a routine sonication period in ice $(3 \times 10 \mathrm{sec})(\mathrm{S} 1)$, and their total mass content determined using the BCA kit (Pierce). Given that the difficulty of the insoluble fibres present in the samples, these were subjected to an additional extensive sonication 
period (S2). Mass-normalized cell lysates (S1 and S2) and media samples $(60 \mu \mathrm{g})$ were subjected to reducing $6.5 \%$ SDS-PAGE in Tris-Glycine buffer, and electrophoretically transferred onto nitrocellulose membranes. Precision Plus Dual Color (Bio-Rad, Amadora, Portugal) were used as protein standards. Immunoblotting of the transferred proteins was performed by incubating membranes $\mathrm{O} / \mathrm{N}$ with the anti-Collagen Type-I primary antibody, after blocking non-specific binding sites with non-fat dry milk in TBS-T $(10 \mathrm{mM}$ Tris- $\mathrm{HCl}$ at $\mathrm{pH} 8.0,150 \mathrm{mM} \mathrm{NaCl}$, $0.5 \%$ Tween). Detection was achieved using a horseradish peroxidase-linked secondary antibody and an ECL kit (GE Healthcare).

\section{Confocal microcopy analyses of Type-I collagen protein distribution}

Cells treated as above (section 2.6.2) were grown on 35 $\mathrm{mm}$ plates-containing pre-treated coverslips and fixed with a $4 \%$ paraformaldehyde PBS solution at 3 DPC. Cells were methanol-permeabilized, non-specific sites blocked by 1 $\mathrm{h}$ incubation with a $3 \%$ bovine serum albumin (BSA)-PBS solution, and coverslips submitted to immunocytochemistry procedures using the anti-Collagen Type-I antibody diluted in 3\% BSA-PBS. Upon three washes with PBS, cells were incubated with the fluorescein isothiocyanate (FITC)-conjugated secondary antibody. Coverslips were mounted on microscope slides with 4',6diamidino-2-phenylindole (DAPI)-containing Vectashield antifading reagent (Vector, Burlingame, CA, USA). Images were acquired in a LSM 510 META confocal microscope (Zeiss, Göttingen, Germany) using an Argon laser line of $488 \mathrm{~nm}$ (FITC channel), and a Diode 405-430 laser (DAPI channel).

\section{Animal model and implantation procedure}

Animal studies were performed according to European regulations and following permission granted by the Ethical Committee. Owing to ethical and economic reasons, only two animals were used for implantation procedures. Two mature male pigs weighting between 40 and $50 \mathrm{~kg}$ were used as experimental animals, for observation periods of 1 month (one pig) and 2 months (the other pig). Injection sites were shaved and cleaned with Betadine (10\% povidone-iodine). The animals were operated under general anaesthesia performed with intravenous injection of ketamine (Ketalar, Pfizer, New York City, NY, USA) and xylazine hydrochloride (Rompun $2 \%$, Bayer, Leverkusen, Germany) under aseptic conditions. To implant the cement pastes, a longitudinal incision on the outer surface of the foot was made until expose the tarsal bone and three circular holes $(\varnothing 3.5 \times 10$ $\mathrm{mm}^{3}$ ) drilled perpendicular to the long axis of the bone with a drill bit (Synthes, West Chester, PA, USA) in each animal. The CPCs to be implanted were prepared by hand mixing for $1 \mathrm{~min}$ and then injected in the cavities with a 5 $\mathrm{mL}$ syringe. The holes were filled, respectively, with $\mathrm{ZnSrCPC}, \mathrm{ZnCPC}$ and reference apatite cement (Norian SRS $^{\circledR}$, Norian Corp., Synthes). In each hole, one marker (skin stapler) was placed into the cement paste, during setting, for localization of the implant position at the end of the implantation period. Setting time of $11 \pm 2 \mathrm{~min}$ after filling the holes was granted for the cements, $\mathrm{ZnSrCPC}$ and $\mathrm{ZnCPC}$, before closing. Norian $\mathrm{SRS}^{\circledR}$ was mixed and applied according to the specifications of the producer. Subcutaneous tissues were closed using resorbable Dafilon 2/0 sutures (Braun, Melsungen, Germany), whereas skin was closed with a skin stapler. Both animals recovered from the operative procedure without incident. Postoperative pain killer, Tramadol (Medinfar, Amadora, Portugal) and antibiotic cefazolina (Labesfal, Fresenius, Campo de Besteiros, Portugal) were administered for 3 days. By the second postoperative day, the pigs began to walk freely with access to food and water. At the end of the predetermined period of implantation ( 1 and 2 months), the animals where operated (not sacrificed) according to the same protocol. Removal of the implants and some surrounding bone was performed using a hollow drill bit of $\varnothing 6.5 \mathrm{~mm}$ (Synthes).

\section{Histological and histomorphometric analyses}

The samples containing the defects with the cements were fixed in 4\% formaldehyde, decalcified in nitric acid and embedded in paraffin. For histological and histomorphometric analysis, cross-sections of $5 \mu \mathrm{m}$ thicknesses were cut (Leica RM 2145 saw microtome; Leica, Wetzlar, Germany) from the middle of the sample towards the periphery and stained with haematoxylin/eosin (H\&E). Haematoxylin stains cells' nuclei and eosin is a fluorescent red acid dye commonly used to stain cytoplasm and collagen, since it binds to proteins in general. Histological and histomorphometric analyses were performed using a laser scanning confocal fluorescence microscope (Zeiss LSM 510 META), equipped with a 561 $\mathrm{nm}$ DPSS laser. To quantitatively determine the amount of newly formed bone, the histological sections were analyzed after both implantation time periods (1 and 2 months). At least $12 \mathrm{H} \& \mathrm{E}$ stained histological sections were randomly chosen for every condition, and each section was observed under a confocal laser scanning microscope at Plan-Neofluar 10x/0.3 magnification (histological and histomorphometrical analyses) and PlanApochromat 100x/1.4 Oil (histological analyses). The removed cylindrical sample $(\varnothing 6.5 \mathrm{~mm})$ contained old trabecular bone at the periphery $(\sim 1.5 \mathrm{~mm}$ at each side). Hence, images of newly formed matrix and bone were taken at the middle and periphery of each section, here on called 'implant area'. A total of 25 microphotographs were taken and analyzed for every condition. The Zeiss LSM 5104.0 image analysis software was used to determine the areas occupied by the total organic material positive for the protein-staining eosin dye and, within this, the areas specifically occupied by newly formed bone or organic matrix. Data is presented as mean \pm standard error of the mean for each implant. The intensity of the fluorescent organic material was also recorded as a measure of density, as microphotographs were taken with the same laser and gain settings.

\section{Statistical analysis}

Statistical significance analysis was conducted using the SPSS (Chicago, IL, USA) 16.0 software, by one way analysis of variance ANOVA, followed by the Tukey- 
Kramer post hoc test, with the level of statistical significance set at $p<0.05$. In vitro data are expressed as means \pm standard error of the mean of at least three independent experiments.

\section{Results}

\section{$\mathrm{ZnCPC}$ and $\mathrm{ZnSrCPC}$ cement powders induce MC3T3-E1 cellular proliferation}

Dose-dependent cell viability and proliferation of MC3T3E1 osteoblastic-like cells cultured on the $\mathrm{ZnCPC}$ and $\mathrm{ZnSrCPC}$ cements for 24,48 , and $72 \mathrm{~h}$ were evaluated by the non-destructive and non-toxic resazurin metabolism assay (Fig. 3a, b). The usefulness of the resazurin assay as a measure of cell proliferation and viability was first tested in a MC3T3-E1 cell proliferation assay, and a linear response could be observed between 1 and $4 \times 10^{4}$ cells $\mathrm{cm}^{-2}$ (Fig. 3). Hence, cells were seeded at $1 \times 10^{4}$ cells $\mathrm{cm}^{-}$ 2 in the presence of different cement powder concentrations and the percentage of cell viability determined (Fig. 3a, b). No cytotoxic effects were observed for any doses of the cement powders used, and cells O.D. increased with time in culture for all conditions. For ZnCPC (Fig. 3a), small increases in cellular proliferation (fold-increases of 1.10-1.30 over control conditions, $0 \mathrm{mg} \mathrm{mL} \mathrm{m}^{-1}$ powder cements) were observed for 0.1 and $1.0 \mathrm{mg} \mathrm{mL}^{-1}$ at $24 \mathrm{~h}$ $(p<0.01)$ and $48 \mathrm{~h}(p<0.05)$. Cells exposure to 0.1 and 1.0 $\mathrm{mg} \mathrm{mL} \mathrm{m}^{-1} \mathrm{ZnSrCPC}$ (Fig. 3b) induced higher dosedependent increases in cellular proliferation, resulting in fold-increases of 1.30-1.50 (for $1.0 \mathrm{mg} \mathrm{mL}^{-1}$ ) over control levels [24 and $48 \mathrm{~h}(p<0.001) ; 72 \mathrm{~h}(p<0.01)]$. A proliferation assay on set cement (blocks) using the unsubstituted $\beta$-TCP as control was also performed (Fig. 2). The proliferation profiles obtained for a given time period were very similar to the ones obtained for the powdered cements (Fig. 3) although a slight delay on the stimulation of proliferation could be observed, most possibly due to a lower contact area between cells and set cements (blocks).

\section{Altered MC3T3-E1 morphology and density in response to cement powders}

After 3 days in culture cell confluency was achieved, as visually confirmed. Of note, the $\mathrm{pH}$ range indicator on cells media (phenol red) revealed no alterations to the physiological $\mathrm{pH}$ 7.4, as confirmed by $\mathrm{pH}$ media measurements (Basic Meter PB-11, Sartorius, Göttingen, Germany). At this time point, morphological analyses of MC3T3-E1 cells exposed to $1 \mathrm{mg} \mathrm{mL}^{-1}$ of $\mathrm{ZnCPC}$ and $\mathrm{ZnSrCPC}$ cement powders revealed some observable differences (Fig. 3c). Phase contrast microphotographs show that cells in contact with cements (arrows) appear to possess a more irregular cell shape, especially for $\mathrm{ZnCPC}$, with increased number of plasma membrane protuberances. A decrease in cellular volume and nucleus (N) size is especially evident for ZnSrCPC-exposed cells, which may correlate with its observed higher rate of cells in a proliferative mode (Fig. 3b). Of note, the higher cellular densities of $\mathrm{ZnSrCPC}$-exposed cultures, evident in

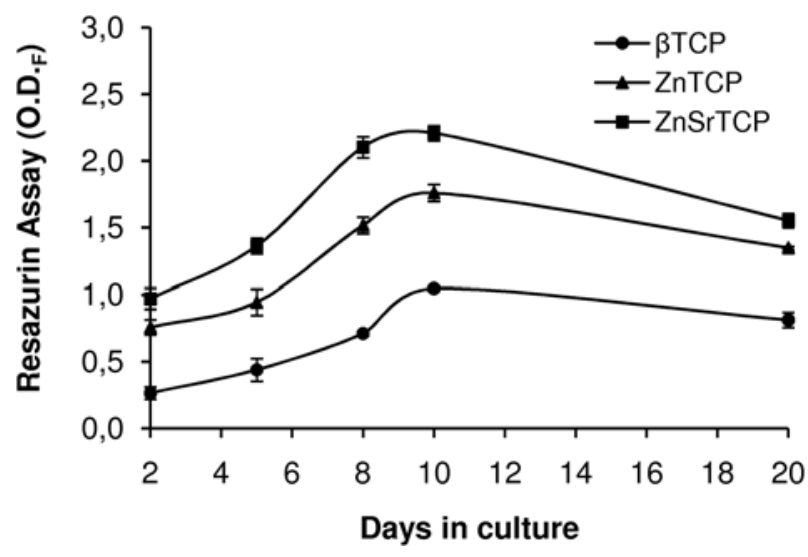

Fig. 2. Cell viability assays of MC3T3-E1 osteoblasticlike cells exposed to $\beta$-TCP, $\mathrm{ZnCPC}$, and $\mathrm{ZnSrCPC}$ cement blocks for 20 days. The resazurin metabolic assay was used to determine the cements cytotoxic and proliferative effects in MC3T3-E1 cells. $5 \times 10^{4}$ cells were seeded in 24 well plates containing the cement blocks, previously incubated for 2 days in cell fresh media. At the indicated time points, cells were incubated with fresh medium containing $10 \%$ of a resazurin solution for $4 \mathrm{~h}$, followed by spectrophotometrical measurements of the resazurin reduction (see section 2.3 in Materials and Methods). Results are presented as Resazurin O.D. mean $\pm \mathrm{SE}$, of three to five independent experiments. Cells incubated in the presence of the $\mathrm{ZnCPC}$ and $\mathrm{ZnSrCPC}$ cement blocks have significantly increased proliferation profiles $(p<0.001)$ when compared to cells incubated in the presence of the unsubstituted $\beta$-TCP cement blocks.

(Fig.3b), can be observed in Fig. 1c microphotographs, which show a higher number of cells (and respective nuclei) and less intercellular space.

\section{The presence of $\mathrm{Zn}$ ions in cements induces ALP activity in long term osteoblastic cultures}

ALP assays were performed in MC3T3-E1 cells exposed to $1 \mathrm{mg} \mathrm{mL}-1$ of cement powders at various days postconfluency (DPC). Results indicated that not only cells maintain their capability to express active ALP enzymes on powdered cements, but even increase it with time in culture (Fig. 4). For all conditions tested, ALP activity was similarly maintained and slightly increased until two weeks in post-confluency culture, after which it rapidly increased until the last time point tested ( $28^{\text {th }}$ day). From days 14 to 28, a known period of MC3T3 cell differentiation/ maturation, ALP activity of cells incubated with ZnCPC and $\mathrm{ZnSrCPC}$ cement powders increased over control levels ( $p<0.05$ for $\mathrm{ZnCPC}$ at days 14 and 21; $p<0.01$ for $\mathrm{ZnCPC}$ and $\mathrm{ZnSrCPC}$ at day 28). Of note, crude ALP activities (non-divided by the samples' total protein mass) of cells exposed to the powdered cements were already higher than control levels starting from day 6 (data not shown), but until day 14 these differences resulted from their higher induction of cell proliferation. Indeed, when these data were normalised per $\mathrm{mg}$ total protein there was no significant difference $(p>0.05)$ (Fig. 4). Results 
(a)

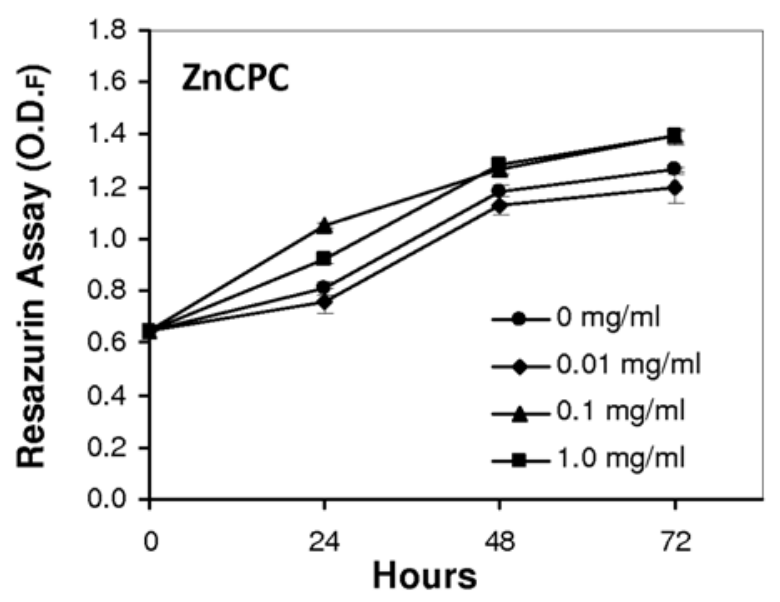

(b)

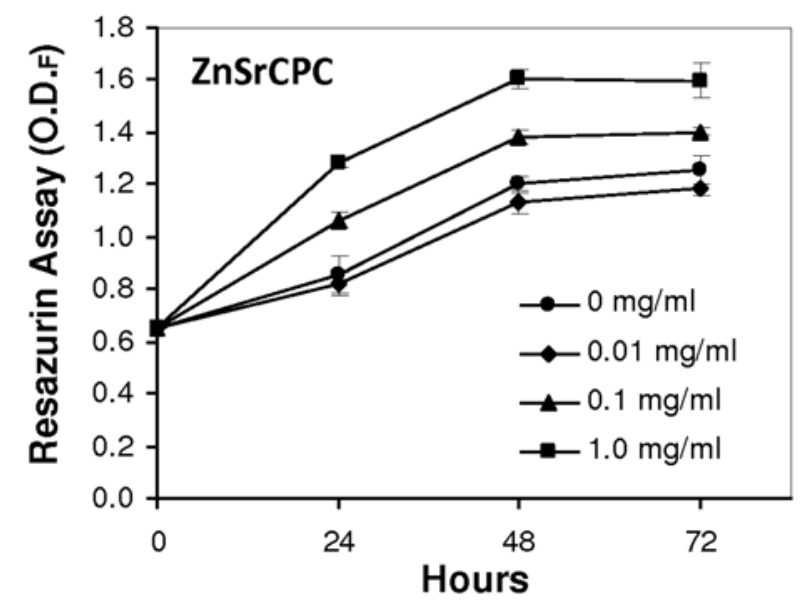

(c)
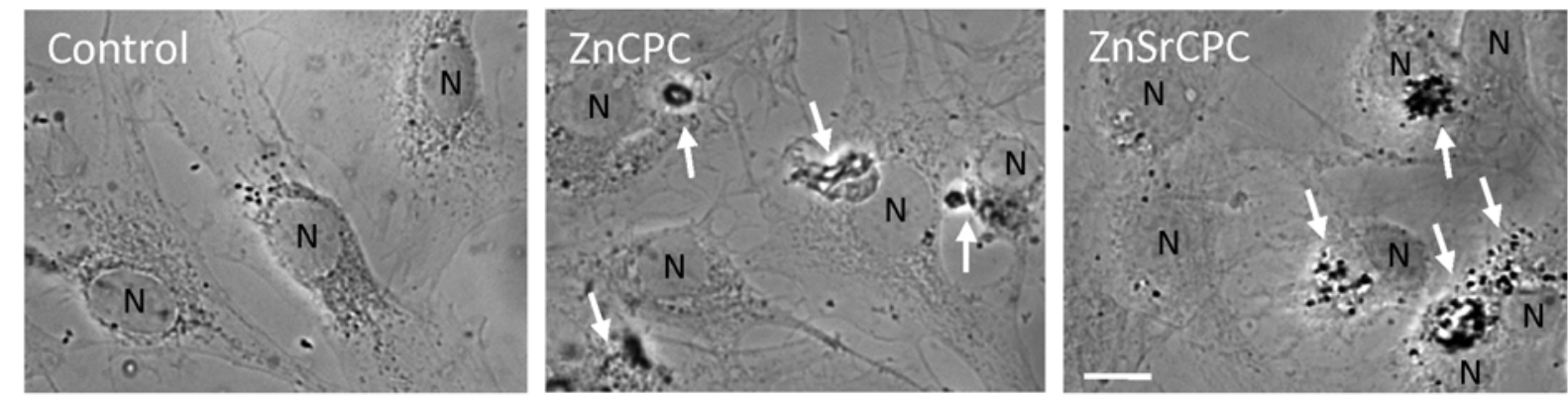

Fig. 3. Cell viability assays of MC3T3-E1 osteoblastic-like cells exposed to $\mathrm{ZnCPC}$ and $\mathrm{ZnSrCPC}$ cement powders: (a) cell viability of cells cultured with increasing concentrations of ZnCPC and (b) ZnSrCPC cement powders for 24, 48 and $72 \mathrm{~h}$; results presented are the mean $\pm \mathrm{SE}$ of at least three independent experiments; (c) phase contrast microphotographs of MC3T3-E1 cells exposed to $1 \mathrm{mg} \mathrm{mL}^{-1}$ of cement powders (ZnCPC and $\mathrm{ZnSrCPC}$ ) for $72 \mathrm{~h}$. N: cells' nuclei. Arrows: visible aggregates of cement powders. Bar $10 \mu \mathrm{m}$.

therefore reflect $\mathrm{ZnCPC}$ and $\mathrm{ZnSrCPC}$-induced variations in the state of cell maturation leading to increased ALP activities.

\section{ZnCPC and ZnSrCPC enhance MC3T3-E1 osteoblasts adhesion capacities}

When collecting cell lysates for analysis of their ALP activity, it was noted that non-exposed control cells were more easily detached from the plate's plastic bottom than cells exposed to $\mathrm{ZnCPC}$ and $\mathrm{ZnSrCPC}$, suggesting that they may exhibit alterations in their adhesiveness. Hence, further studies assayed differential adhesion capacities of MC3T3-E1 cells exposed to the cement powders. Upon 0, 3 , and 14 DPC cell culture, a time-dependent increase in the capacity of MC3T3-E1 cells to adhere to a plastic support was observed (Fig. 5), but decreasing until day 21. Both $\mathrm{ZnCPC}$ and $\mathrm{ZnSrCPC}$ cement powders were able to increase cell adhesion, in comparison with non-exposed control cells $(p<0.05$ at 0,3 and $21 \mathrm{DPC}$ and $p<0.001$ at $14 \mathrm{DPC}$ for $\mathrm{ZnCPC} ; p<0.001$ for $\mathrm{ZnSrCPC}$ at $14 \mathrm{DPC}$ ). Hence, $\mathrm{ZnCPC}$ was even slightly more effective while the $\mathrm{ZnSrCPC}$ cement appeared to have an intermediate behaviour between control and $\mathrm{ZnCPC}$ exposed cells at days 0 and 3, possibly reflecting a higher number of $\mathrm{ZnSrCPC}$ dividing cells, known to be less adhesive.

\section{ZnSrCPC alters SDS-PAGE Type-I procollagen migration profiles and enhances formation of extracellular fibrils}

The effect of the cements on collagen protein levels, secretion and fibrillar deposition was studied by immunoblot and immunocytochemistry analyses. In terms of immunoblot bands profile, collagen is somewhat complex (Fig. 6). Monomeric Type-I procollagen consists of $\alpha 1(\sim 140 \mathrm{kDa})$ and $\alpha 2(\sim 130 \mathrm{kDa})$ chains, which are intracellular processed (signal peptide cleavage, hydroxylation of proline and lysine residues, glycosylation of lysine residues). Alpha chains can intracellularly associate into dimers $(\sim 270 \mathrm{kDa})$ and trimers $(\sim 400 \mathrm{kDa}$; triple helix consisting of two $\alpha 1$ and one $\alpha 2$ chains). There is some covalent cross-linking already within these forms, which are not breakable by SDS-PAGE denaturing conditions (Lareu et al., 2006). All these cell-associated Type-I pro-collagen forms were present in all samples and a time-dependent profile for the various cellular procollagen forms could be observed (Fig. 6a). Between 


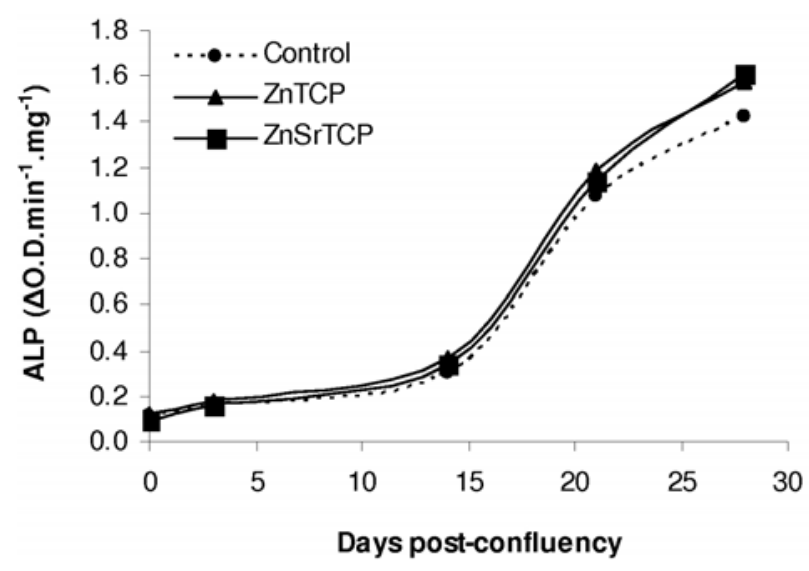

Fig. 4. Alkaline phosphatase (ALP) activity of MC3T3E1 cells cultured on $1 \mathrm{mg} \mathrm{mL}^{-1} \mathrm{ZnCPC}$ and $\mathrm{ZnSrCPC}$ powdered cements for several days $(0,1,3,6,14$ and 21) post-confluency. The ALP activity was expressed as the increase in p-nitrophenol absorbance per min per microgram of protein $\left(\Delta \mathrm{OD} \cdot \mathrm{min}^{-1} \cdot \mathrm{mg}^{-1}\right)$. Results presented are the mean of two independent experiments.

0, 3 (proliferation period) and 14, 21 (maturation period) DPC, a high increase (3-4 fold-increase) in the levels of cellular pro-collagen is noted, especially for the dimeric $\beta(\mathrm{I})$ and trimeric $\gamma(\mathrm{I})$ forms . In panel (a), levels of cellassociated Type-I pro-collagen were in the following order: Control $>\mathrm{ZnSrCPC}>\mathrm{ZnCPC}$, except at $3 \mathrm{DPC}$.

Remarkably, the cements collagen levels at 14 and 21 DPC strongly increased following extensive samples sonication (panel b), which permitted the visualization of cell layer-associated fibrils F(I) and $\gamma(\mathrm{I})$ ) forms, and their breakdown products (Fig. 6b). Further, this allowed detecting an increase in the formation of collagen fibrils for $\mathrm{ZnSrCPC}$ at $3 \mathrm{DPC}$, observable in all experimental determinations. Surprisingly, ZnSrCPC-induced alterations in the electrophoretic migration of all procollagen monomer and dimeric bands could also be denoted (Fig. $6 a, b$ “*”), revealing higher levels of post-translational procollagen modifications. This also occurred to a lower extent for $\beta$ chains in $\mathrm{ZnCPC}$ samples.

Intracellular procollagen is exported to the trans-Golgi network (TGN) to be medium secreted. Extracellularly, $\gamma$ chains are enzymatically processed into tropocollagen, promoting their aggregation into cell layer-associated collagen microfibrils and fibrils (Sweeney et al., 2008). Hence, the levels of medium soluble procollagen were also analysed (Fig. 6c). It could be observed that procollagen secretion (peaking at 3 DPC) precedes, as expected, trimeric procollagen, tropocollagen and fibril formation (abundant from 14 DPC onward). Fig. 6c shows higher procollagen secretion for $\mathrm{ZnCPC}$ and $\mathrm{ZnSrCPC}$-exposed cells at 3 DPC $(p<0.05)$, and lower for 14 and 21 DPC, suggesting higher depletion of intracellular collagen at 3 DPC.

In order to confirm the immunoblot observations at 3 DPC, and as collagen antibodies exhibit a higher degree of specificity under non-denaturing native conditions, cells were subjected to microscopy analysis of Type-I collagen cellular distribution and fibril deposition (Fig. 5).

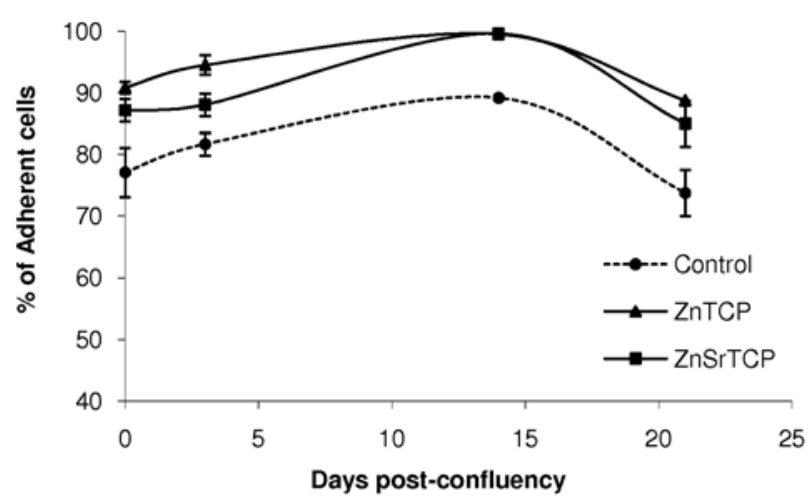

Fig. 5. $\mathrm{ZnCPC}$ and $\mathrm{ZnSrCPC}$-dependent MC3T3-E1 cells' adhesion capacities. The capacity of cells to adhere to a plastic support for $1 \mathrm{~h}$ was measured following cell exposure to the cement powders for $0,3,14$ and 21 days post-confluency. At each experimental day, $1 \mathrm{x}$ $10^{5}$ cells were seeded into 24 -well plates and left to adhere for $1 \mathrm{~h}$ at $37^{\circ} \mathrm{C}$. Media was further collected and the number of non-adherent ressuspended cells counted (x). The percentage of adherent cells was calculated $\left(1 \times 10^{5}-\mathrm{x}\right)$, taking the initial $1 \times 10^{5}$ cells as $100 \%$. Results presented are the mean $\pm \mathrm{SE}$ of three independent experiments.

Consistent with the immunoblot results of Fig. $6 \mathrm{~b}$, the overall levels of intracellular collagen at 3 DPC were in the following order: $\mathrm{ZnSrCPC}>$ Control $\cong \mathrm{ZnCPC}$, but collagen was differently distributed. While for control cells, procollagen mainly accumulated inside intracellular granule-like densities (Fig. 5, arrowheads), for $\mathrm{ZnCPC}$ and $\mathrm{ZnSrCPC}$-exposed cells intracellular procollagen was found in smaller but more numerous cytoplasmic vesicles. These results suggest $\mathrm{CPC}$-induced alterations in the mechanisms of collagen secretion. Further and more remarkable, the extracellular cell-associated collagen fibres (Fig. 7, 'F(I)') were generally longer and denser for cells exposed to cements, especially for $\mathrm{ZnSrCPC}$, confirming an earlier/enhanced aggregation of tropocollagen into fibrils and fibres.

\section{ZnCPC and ZnSrCPC improve osteoconductivity in bone defects}

The excellent in vitro properties observed for the cements led to the analysis of their in vivo osteoconductive and biocompatible properties following implantation in trabecular pig bone defects. Transversal sections of 1 and 2 month implants were stained with H\&E dyes, taking advantage of the fluorescent properties of eosin (Fua et al., 2006), histological and histomorphometric analyses were conducted using a confocal laser scanning microscope. Eosin is an acidic coloured and fluorescent dye that stains proteins but not nuclei or lipids. Hence, in fluorescent microscopy, the organic protein material appears red and the nuclei and lipids appear black. Microphotographs of implant cross-sections revealed that newly formed bone (NB) has grown from the periphery inwards (Fig. 8). Organic protein-containing matrix (Mx) was also observed, although at higher amounts at 1 month of implantation and less after 2 months. Of note, no 


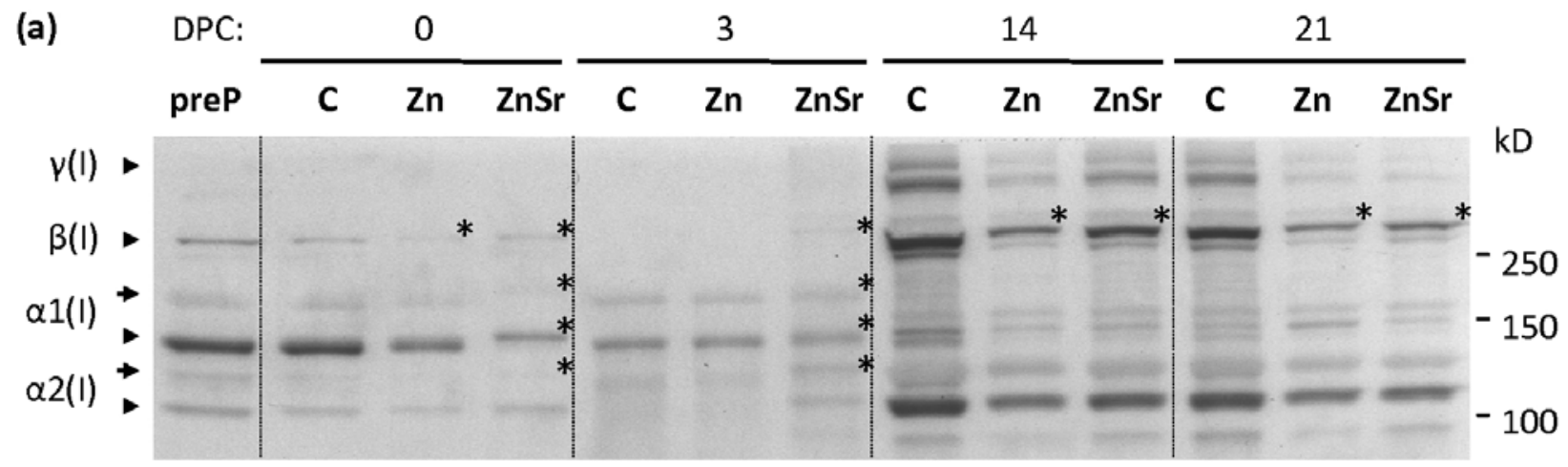

(b)

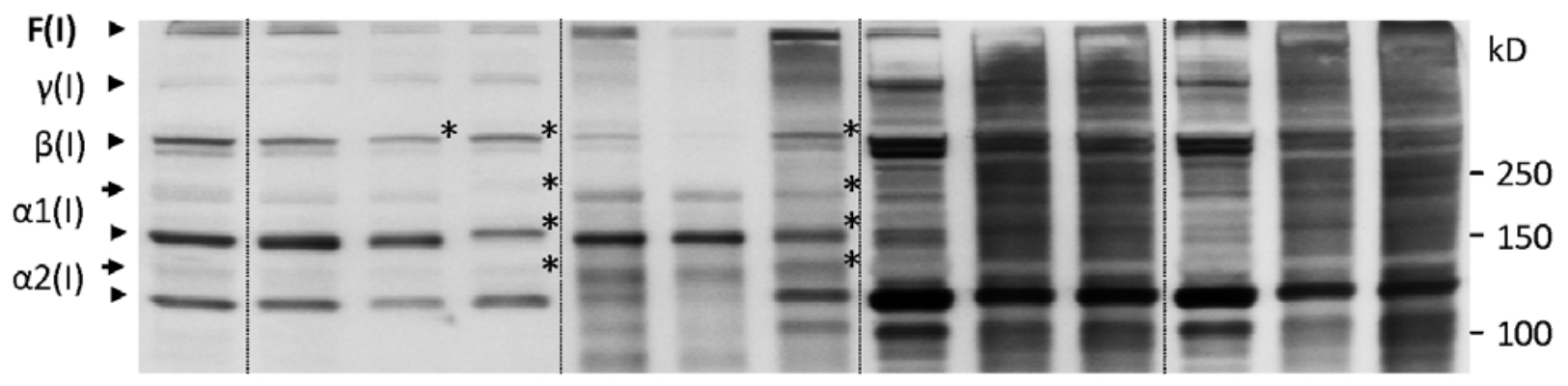

(c)

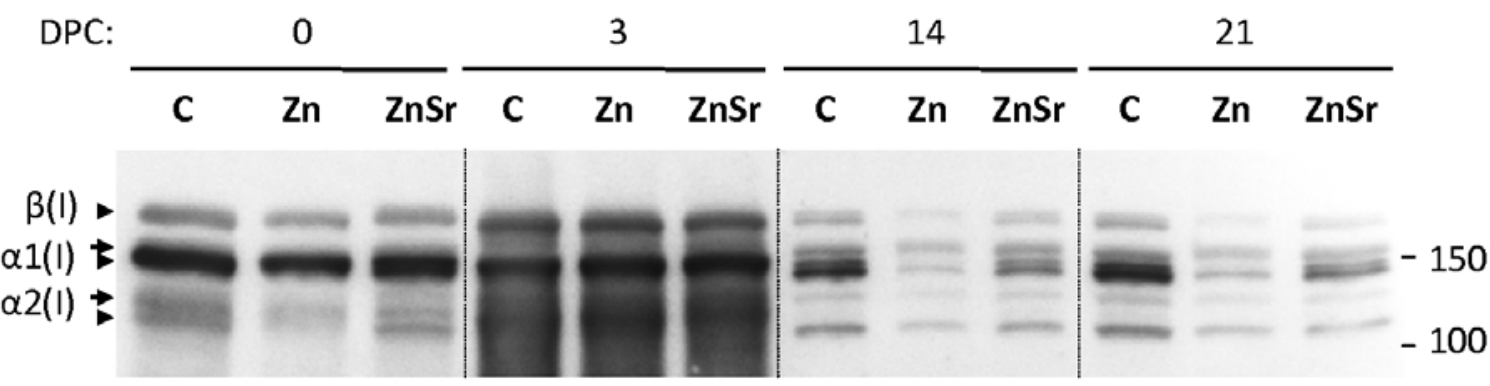

Fig. 6. Immunoblot analysis of cell-associated and medium secreted Type-I collagen with time in post-confluency culture. MC3T3 cells lysates (a,b) and conditioned media (c) were collected at days 0, 3, 14 and 21 of post-confluency culture (DPC). Samples were resolved under reducing conditions and Type-I collagen was immunodetected. Panel (a) corresponds to lysates submitted to S1 (routine sonication), and panel (b) to the same lysates submitted to S2 (extensive sonication, for partial fibres breakdown, which allow for their gel entry and visualization by immunoblot procedures). Note that collagen protein profiles and levels are equal in pre-plated (preP, cells initially plated) and control 0 DPC cells, as expected. $\alpha 1$ (I) and $\alpha 2(\mathrm{I})$, procollagen monomeric chains, unprocessed (arrowhead $\triangleright$ ) and processed (arrow $\Rightarrow$ ); $\beta(\mathrm{I})$, procollagen dimeric forms; $\gamma(\mathrm{I})$, procollagen trimeric forms; $F(\mathrm{I})$, collagen fibres. Migration of molecular weight markers is indicated to the right.

inflammation or other complications associated with the implanted materials were observed throughout the experimental periods.

Three different osteoconductive profiles were denoted for Norian (control), ZnCPC, and ZnSrCPC cements. For Norian and $\mathrm{ZnCPC}$, at 1 month new bone was mainly found at the implant periphery (Fig. 6a,b), while the centre presented black areas and areas filled with cells-enriched unorganized matrix, probably corresponding to active remodelling areas of osteoid secretion and cement and bone callus resorption (Fig. 6a and b). Of note, osteoclast-like cells occur within these areas, while being only sparsely found in $\mathrm{ZnSrCPC}$ sections (Fig. 9). The fact that these areas were almost absent for $\mathrm{ZnSrCPC}$ (Fig. 8c) and the presence of high amounts of NB suggest higher rates of $\mathrm{ZnSr}$ cement resorption and subsequent bone formation during the first month of implantation. Of note, especially for $\mathrm{ZnSrCPC}$, osteoblast-like cells (OB) could be observed in organized matrix that appears to lay foundations for the new bone being formed, that is found in very close relation with it (Fig. 9b). Further, the new bone being deposited after 1 month increases in organization in the following order: Norian $<\mathrm{ZnCPC}<\mathrm{ZnSrCPC}$ (Fig. 8a-c), in terms of trabeculae number, shape and distribution throughout the implant area. In the $\mathrm{ZnSrCPC} \mathrm{(Fig.} \mathrm{8c),} \mathrm{NB} \mathrm{was} \mathrm{mainly}$ found in trabeculae-like concentric structures and crossing the section. For ZnCPC (Fig. 8b) similar structures could also be found but in less concentric structures and mainly 

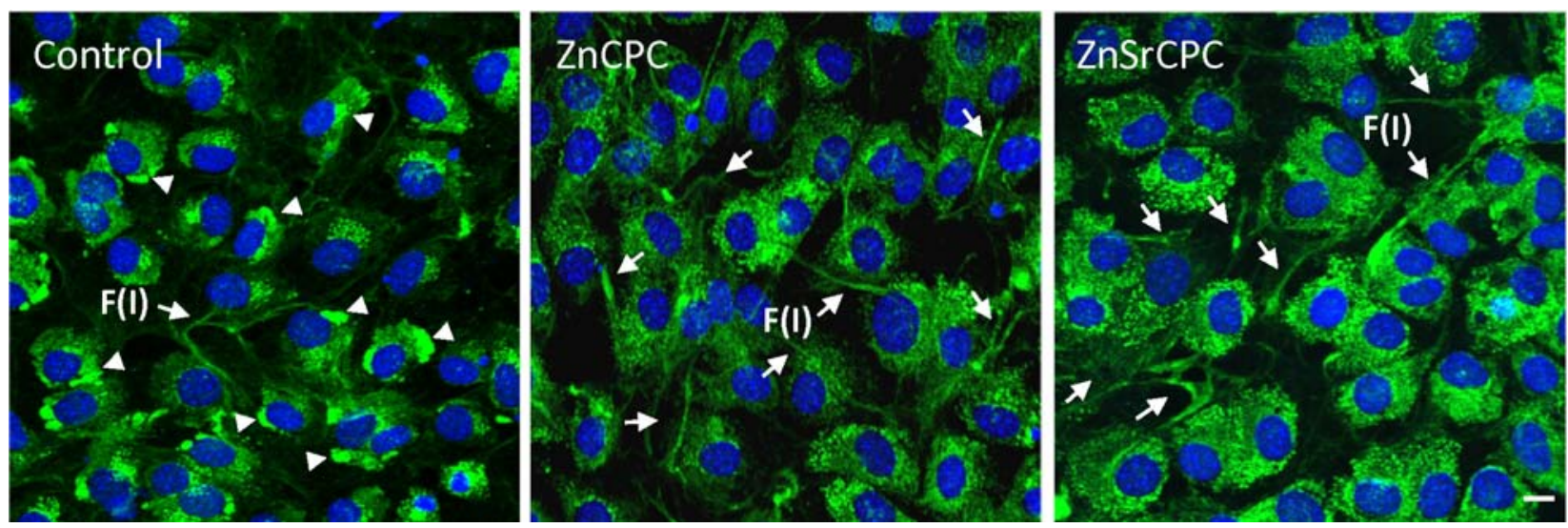

Fig. 7. Confocal microscopy analysis of intra and extracellular Type-I collagen at 3 days post-confluency (3 DPC). Cells in the absence of (Control) or exposed to $1 \mathrm{mg} \mathrm{mL}^{-1} \mathrm{ZnCPC}$ and $\mathrm{ZnSrCPC}$ for 3 DPC (a total of 6 days of exposition) were subjected to immunocytochemistry procedures in order to detect Type-I collagen distribution (green fluorescence) by confocal microscopy. Arrowheads, intracellular granule-like densities. F/arrows, extracellular cellassociated collagen fibres. DAPI (blue fluorescence), nuclear marker. Bar, $10 \mu \mathrm{m}$.

1 month
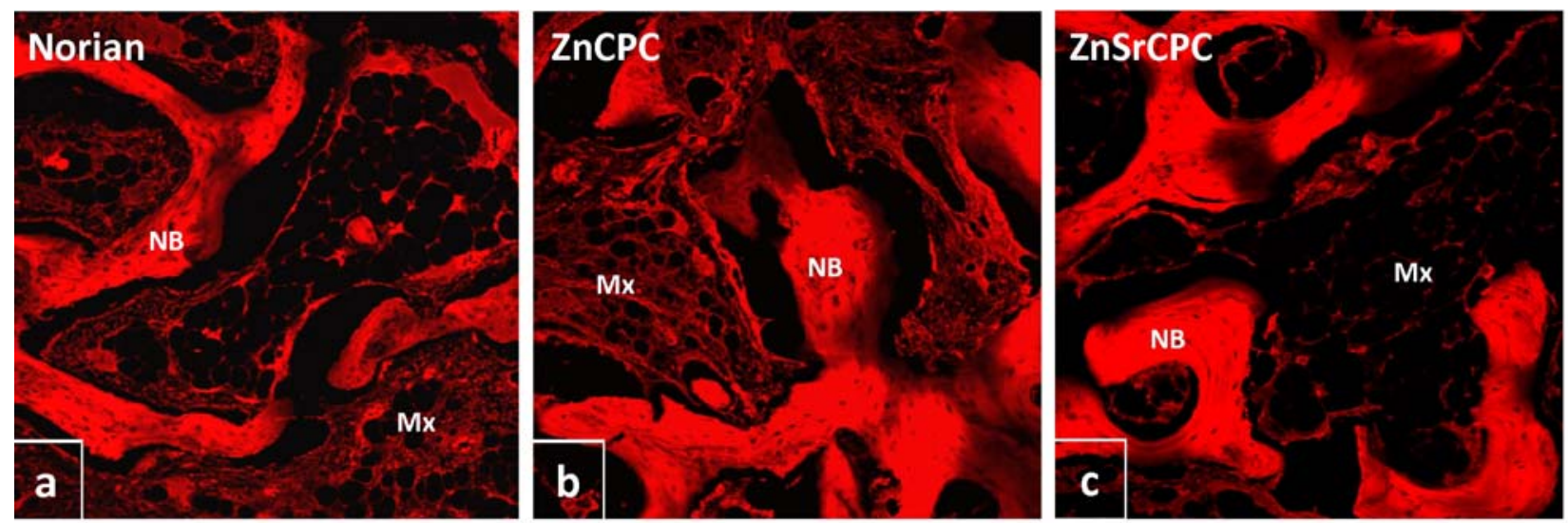

2 months
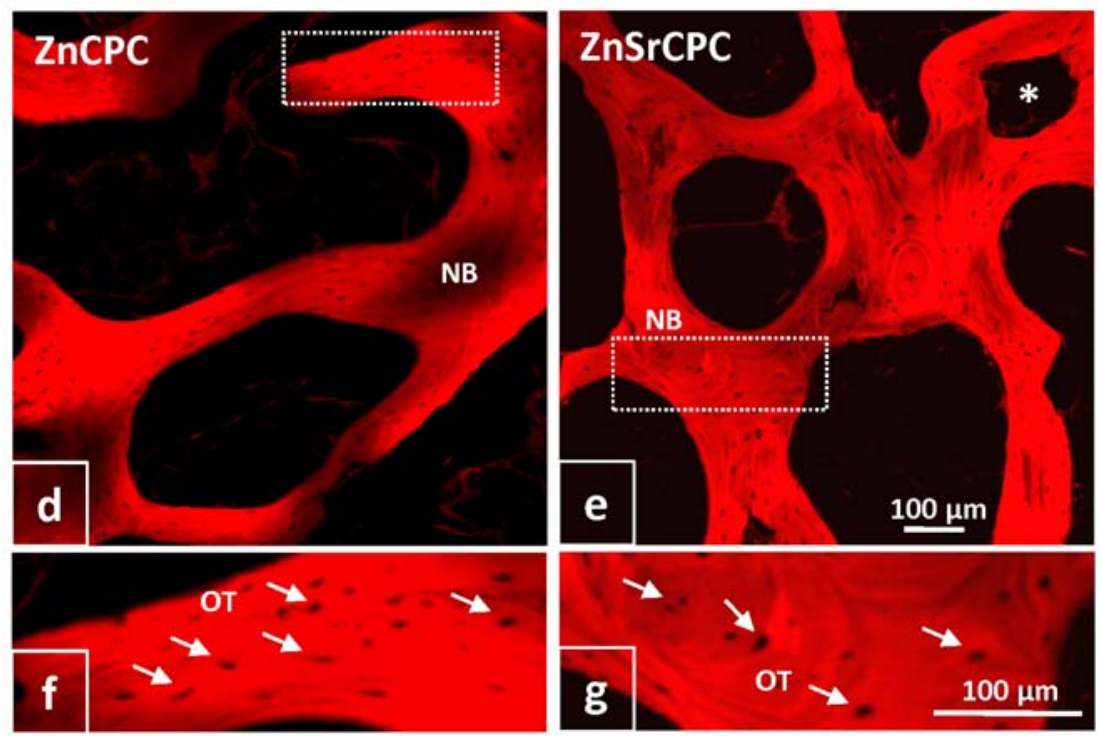

Fig. 8: Confocal fluorescent micrographs of histological H\&E stained sections, showing the tissue osteogenic response to Norian $\operatorname{SRS}^{\circledR}(\mathrm{a}), \mathrm{ZnCPC}(\mathrm{b}, \mathrm{d}, \mathrm{f})$ and $\mathrm{ZnSrCPC}(\mathrm{c}, \mathrm{e}, \mathrm{g})$ cements after 1 (a-c) and 2 (d-g) months of implantation. NB: new bone; Mx: protein matrix; arrows/OT in g,h: osteocytes. 

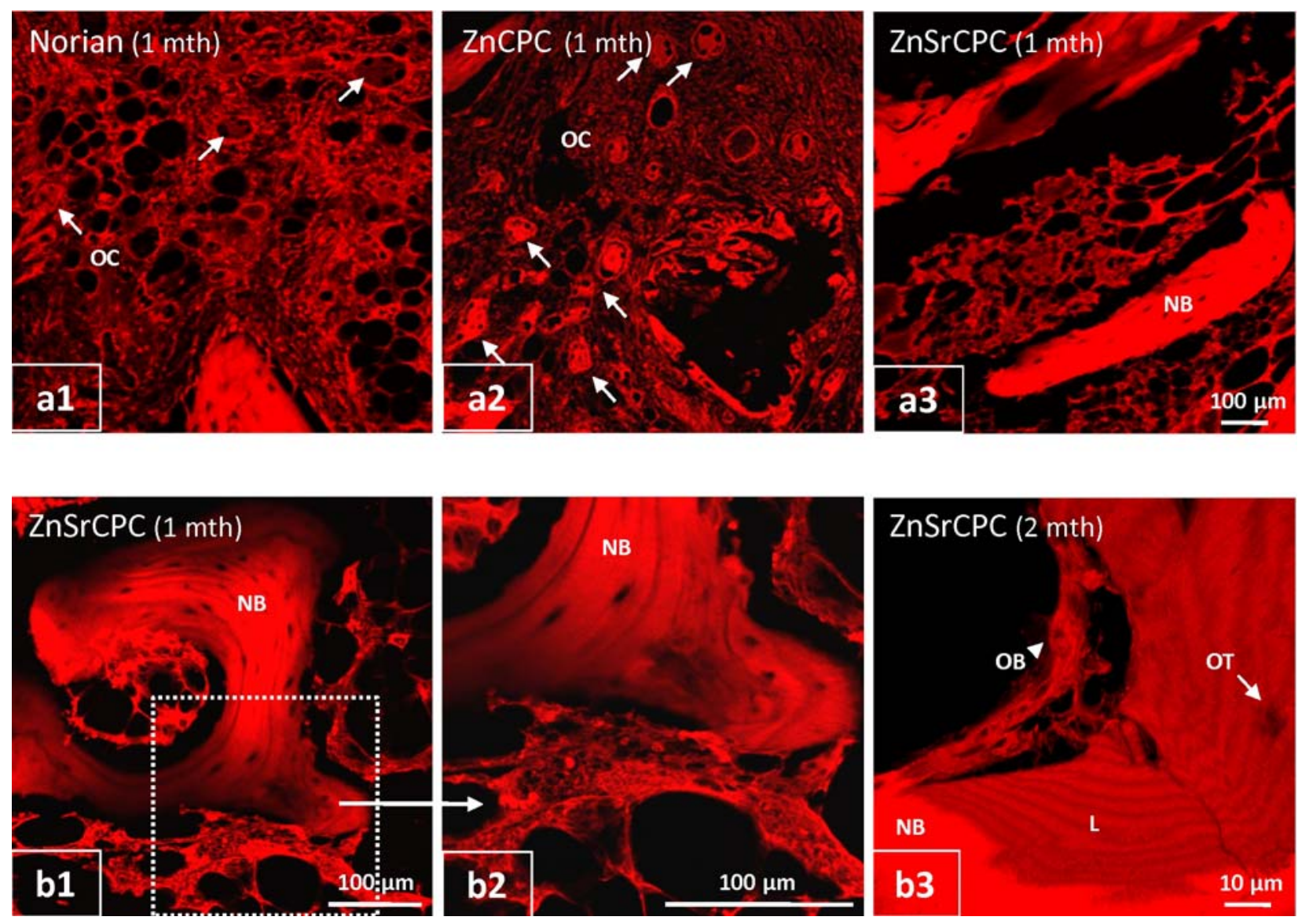

Fig. 9. Confocal fluorescence micrographs of H\&E stained sections, showing histological details of the tissue osteogenic response to Norian $\operatorname{SRS}^{\circledR}(\mathbf{a} 1), \mathrm{ZnCPC}$ (a2) and ZnSrCPC (a3,b1-3) cements after 1 and 2 months (mth) of implantation. OC: osteoclast-like cells, indentified by their multiple nuclei and high protein-dense cytoplasm (arrows); NB: new bone; OB: osteoblast-like cells; OT: osteocytes; L: lamellae. Images from a to b1 were taken with a 10x objective and zoomed 1.5-2x, and b2 was zoomed 4x; b3 represents an image projection of a z-stack, taken with a 100x objective. (S3)

at the periphery of the implant, while for Norian, the new bone was mainly deposited in less circular and lengthy structures (Fig. 8a).

Following 2 months of implantation (Fig. 8d,e), the concentric lamellae deposition into trabecular bone becomes obvious and closed circular trabeculae are the main structures found, especially for $\mathrm{ZnSrCPC}$ implants. For this time period, it was not possible to distinguish new bone from host old trabecular bone at the periphery of the ZnSrCPC implants (Fig. 10). The continuity between new and old bone and within the newly formed trabeculae was notorious for the $\mathrm{ZnSrCPC}$ and less for $\mathrm{ZnCPC}$ (Fig. 10). Fig. 8f and $8 \mathrm{~g}$ show magnified structures of Fig. $8 \mathrm{~d}$ and $8 \mathrm{e}$, where arrows indicate osteocytes (OT) black nuclei. These are mature osteoblasts that are trapped inside bone, occupying small cavities known as lacunae at the junctions of the lamellae, visible in all photos of newly formed bone. The layers of deposited lamellae are also visible (Fig. 9b3). Of note, accordingly with the $\mathrm{ZnSrCPC}$ high induction of in vitro osteoblastic-cells proliferation and differentiation, after 1 month of in vivo implantation a high number of osteoblasts (OB) could be observed adjacent to newly formed bone (NB) (Fig. 11). Note the highly defined canaliculi of the $\mathrm{OB}$ at the left, appearing to be differentiating into an osteocyte (OT).

\section{ZnSrCPC has excellent osteoconductive properties}

The deposition of more organized new bone in $\mathrm{ZnSrCPC}$ implants, as early as 1 month, suggests that this cement presented higher osteoconductive properties in comparison with $\mathrm{ZnCPC}$, possibly due to a higher osteoblast induction. The excellent $\mathrm{ZnSrCPC}$ osteoconductive properties were confirmed by histomorphometric analyses of the in vivo cross-sections. The percentage of area occupied by new organic proteinaceous material was determined (Fig. 12). At 1 month of cement implantation, total proteinaceous area increased as follows: Norian $<\mathrm{ZnSrCPC}<\mathrm{ZnCPC}$. Detailed analysis clarified that while for $\mathrm{ZnSrCPC}$ this proteinaceous material was almost exclusively new bone, for $\mathrm{ZnCPC}$ this equally corresponded to new bone and matrix. From 1 to 2 months of implantation, the percentage of matrix in the implant decreased as osteogenesis continued, and the area of $\mathrm{ZnSrCPC}$ 'black space' also decreased as new bone formation increased (data not shown) reinforcing that, with time of implantation, cement was being resorbed as new-bone formed. Accordingly, new bone fluorescence intensity increased between 1 and 2 months of implantation while matrix average intensity decreased, indicating an increase in bone average density and resorption of initially unorganized protein matrix and bone callus (data not shown). Osteoconductivity was more 

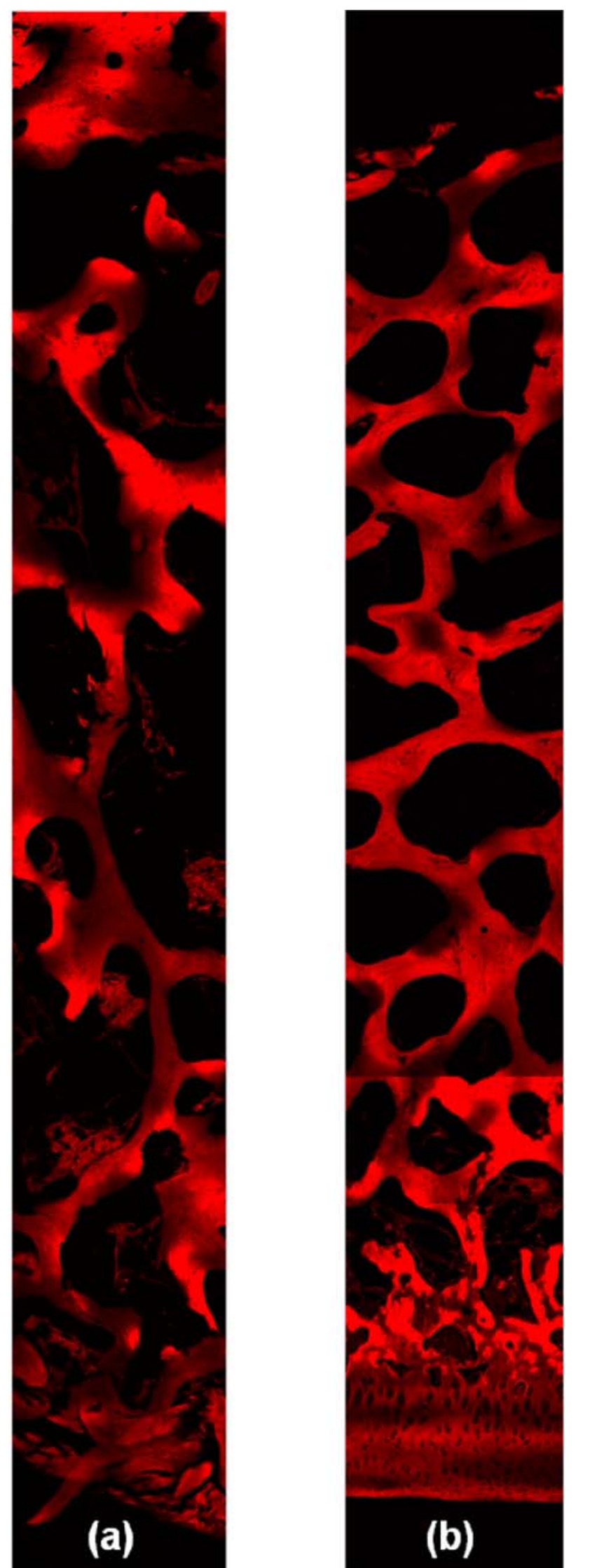

evident for $\mathrm{ZnSrCPC}$, which showed a notorious increase in the area occupied by new bone, reaching $50.0 \pm 5.1 \%$ of the implant area (compared to $34.7 \pm 8.7 \%$ for $\mathrm{ZnCPC}$ ).

\section{Discussion}

The present study examined and compared the in vitro and in vivo response of an osteoblast-like cellular line (MC3T3E1 cells) and two brushite-forming $\mathrm{Zn}$ and $\mathrm{ZnSr}$-containing CPCs and their capacity to conduct osteoregeneration after being implanted in pig trabecular bone. Osteoblasts play a central inhibitory role in the pathophysiology of osteoporosis, where reduced bone mass and deterioration in bone microarchitecture lead to enhanced skeletal fragility. Osteoporosis results from a negative balance between the bone-forming activities of osteoblasts and the resorptive activities of osteoclasts. Inadequate osteoblast activity may result from a relative deficiency in proliferation or differentiation of osteoprogenitors, or from their excessive apoptosis. Hence, it is important to develop biomaterials with the capacity to stimulate osteoblastic proliferation and differentiation, and able to positively assist osteoregeneration.

The MC3T3-E1 cell line has the capacity to differentiate into osteoblasts and osteocytes, and has been demonstrated to have high ALP activity, to secrete collagen and to form calcified bone tissue in vitro, thus providing an excellent model to study the cellular and molecular responses to the biomaterials tested. Dose-dependent proliferation of MC3T3-E1 osteoblastic-like cells cultured on either $\mathrm{ZnCPC}$ or $\mathrm{ZnSrCPC}$ cements confirmed their biocompatibility and capability of induction of cellular proliferation (Fig. 1). These results are consistent with previous studies, where another zinc-releasing CPC with a zinc content of $1.20 \mathrm{wt} \%$ was also able to significantly promote MC3T3-E1 proliferation in vitro (Ito et al., 2000; Kawamura et al., 2000). Our data further revealed that the incorporation of $\mathrm{Sr}$ into brushite cement greatly enhances osteoblastic proliferation in a dose-dependent manner (Fig. $1 b)$, visually confirmed by the higher cellular density of $\mathrm{ZnSrCPC}$ cultures (Fig. 1c). Thus, the $\mathrm{ZnCPC}$ and $\mathrm{ZnSrCPC}$ cements behaved in accordance with results obtained by other authors, where Sr-containing ionic cements were more osteoconductive than Zn-containing ionic cements (Johal et al., 2002). Additionally, ALP activity and collagen secretion and fibre deposition also implicated $\mathrm{ZnCPC}$ and $\mathrm{ZnSrCPC}$ in osteoblastic differentiation. The cements were able to increase MC3T3E1 cells ALP activity over control levels at later periods in culture (Fig. 2), which indicates their higher maturation state at this period. Otsuka et al. (Otsuka et al., 2004) have observed that MC3T3-E1 cells' ALP activity is lower for the first 2 weeks in culture (proliferative state), while increasing from days 15 to 35 , and related this increase to the cells' maturation state. MC3T3-E1 maturation is reached following $\sim 14$ days in culture (Owen et al., 1990; Stein et al., 1989), with ALP activity being used as an indicator of cell differentiation (Lecoeur et al., 1997). The results here obtained indicate that MC3T3-E1 cell
Fig. 10. Contiguous fluorescent microphotographs were taken of histological sections of $\mathrm{ZnCPC}$ (a) and using an Olympus IX81 epifluorescence microscope. (S4) $\mathrm{ZnSrCPC} \mathrm{(b)} \mathrm{cements} \mathrm{upon} 2$ months of implantation, 
PhC

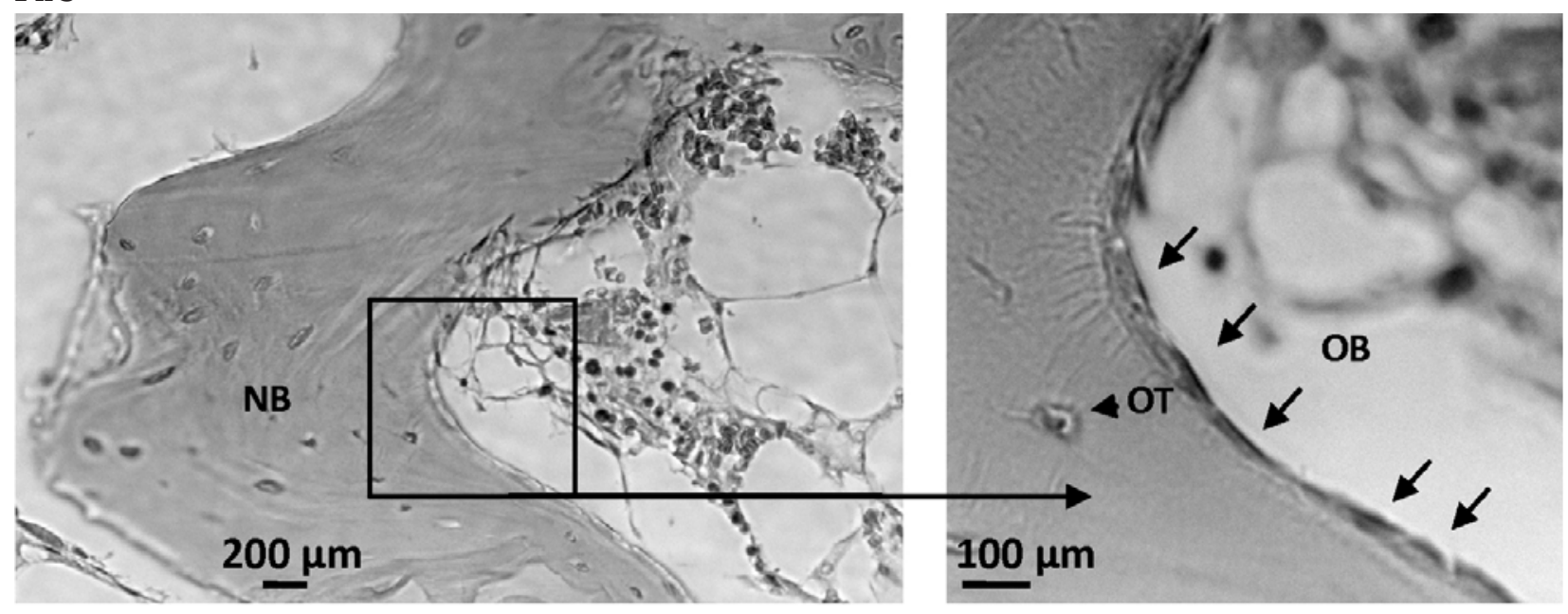

Fluorescence

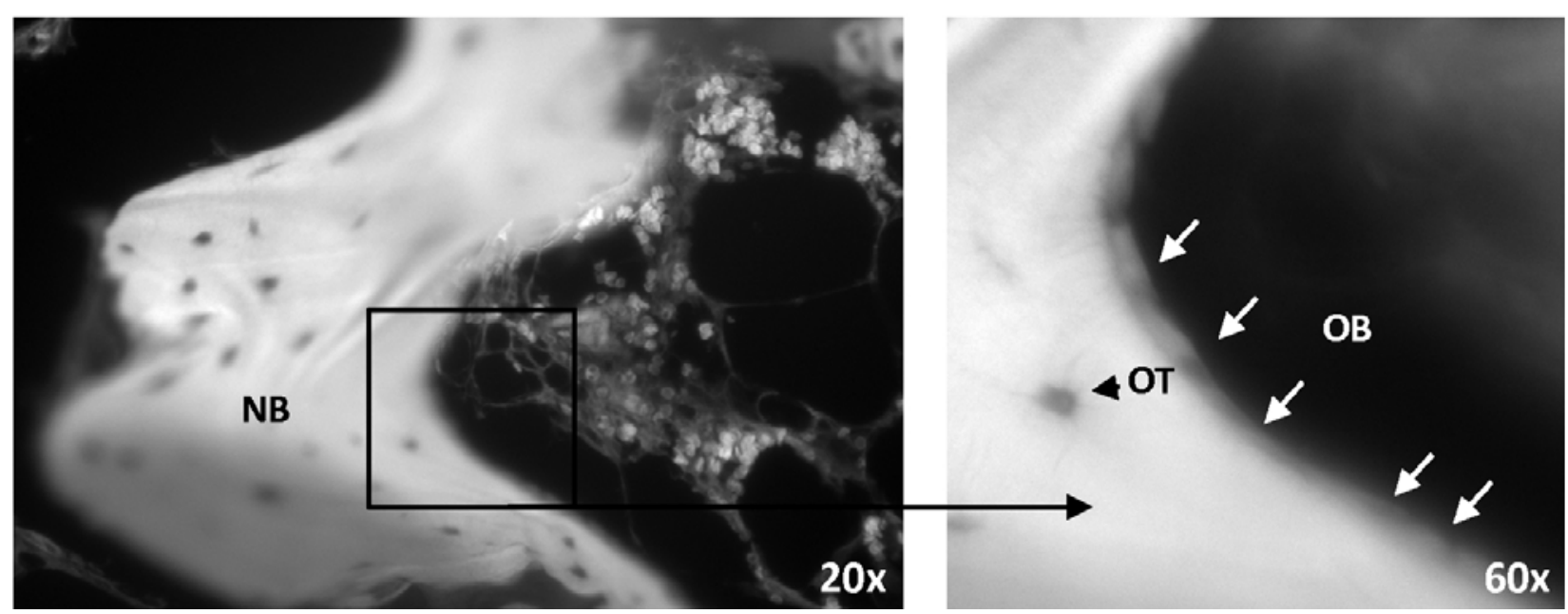

Fig. 11. Microphotographs of a $\mathrm{ZnSrCPC} 1$ month ( $\mathrm{mth}$ ) implant cross-section. Phase contrast (PhC) and correspondent fluorescence (Fl) microphotographs were taken using an Olympus IX81 epifluorescence microscope. Zoomed area denotes osteoblasts (OB) adjacent to the new formed bone (NB) and bone embedded osteocytes (OT).

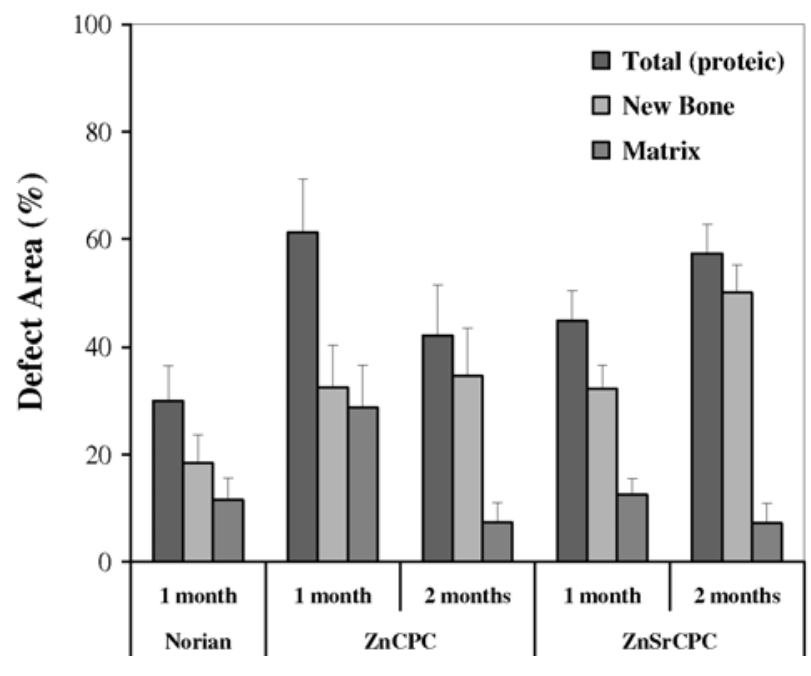

Fig. 12. Histomorphometric analysis of the implant areas of $\mathrm{H} \& \mathrm{E}$ stained sections of $\mathrm{ZnCPC}, \mathrm{ZnSrCPC}$ and Norian $\mathrm{SRS}^{\circledR}$ cements for 1 and 2 months of implantation. The percentage $(\%)$ of the implant area occupied by: new bone formed, protein matrix and both ('Total proteic'). For each condition, twelve crosssections were analysed and error bars represent variation within each implant cylinder. 
maturation mainly occurs at the $14^{\text {th }}$ day in culture, when ALP activity increases (Fig. 2). This is in accordance with the results on protein content determined for ALP assays (data not shown) that revealed an increase in total protein content until 14 days in culture that further decreased and stabilized until the last day tested ( $28^{\text {th }}$ DPC). In summary, results showed that both CPCs can increase osteoblastic cells maturation in terms of ALP activity. Further, as $\mathrm{ZnCPC}$ and $\mathrm{ZnSrCPC}$ results are virtually equal, $\mathrm{Zn}$ ions appear to be the relevant inducers of ALP activity, as expected since this is a $\mathrm{Zn}$-dependent enzyme (McComb et al., 1979).

Subsequent data demonstrated that $\mathrm{ZnCPC}$ and $\mathrm{ZnSrCPC}$ were also able to increase osteoblasts intrinsic cell-to-matrix adhesion capacities (Fig. 3), what can be relevant in the osteoconductive process, e.g. for osteoblasts adhesion to the protein matrix and to new bone. This was first observed visually when collecting cells lysates for ALP determination, where cells grew in the presence of the cements biofilms, attached more tightly to the plastic support. Indeed, cells previously exposed to the cement powders exhibited higher adhesive capacities to a new plastic support (Fig. 3). Of note, during the proliferative period (e.g. 3DPC), the adhesiveness of cells exposed to $\mathrm{ZnSrCPC}$ were slightly lower than for $\mathrm{ZnCPC}$ exposed cells. This may again correlate to its higher induction of cellular division and with the fact that dividing cells are more loosely connected to the support than interphase cells. Of note, the higher number of cell membranar protuberances observed for $\mathrm{ZnCPC}$ cells (Fig. 1c) suggests altered cytoskeleton dynamics, potentially related to its altered adhesiveness. Interestingly, all cells exhibited a decrease in their intrinsic adhesive capacities in the differentiation period (Fig. 3, 14-21 ${ }^{\text {st }}$ DPC) which might be correlated with their increased dependence on an extracellular matrix. Indeed, this corresponds to the period of higher deposition of extracellular collagenous matrix (ECM), as observed in Fig. 4b. Immunoblot and immunocytochemistry methods revealed that CPCs induced alterations in MC3T3-E1 collagen production, secretion and extracellular fibres formation. In essence, cements enhanced collagen secretion in the predifferentiation period (3 DPC, Fig. 4c) correlate well with their subsequent higher collagen fibre formation in the differentiation period (14 and 21 DPC, Fig. 4b). Additionally, ZnSrCPC induces a higher rate of collagen aggregation into fibres, as early as at 3 DPC, as confirmed by both immunoblot and immunocytochemistry analyses (Fig. 4b and 5). Indeed, in $\mathrm{ZnSrCPC}$ exposed cells, TypeI collagen fibres were observed to be longer and denser, suggesting an earlier/enhanced aggregation of tropocollagen into fibrils and fibres. This may be related to the observed altered SDS-PAGE migration profiles of procollagen in $\mathrm{ZnSrCPC}$ cell lysates (Fig. 4a and b '*'), which reflect a higher level of protein post-translational modification, potentially proline hydroxylation and subsequent hydroxylysine glycosylation. Indeed, hydroxyproline and hydroxylysine, which derive from proline and lysine hydroxylation at the endoplasmic reticulum, are necessary for the formation and stabilization of collagen, playing key roles in collagen stability (Nelson et al., 2005). Hence, $\mathrm{ZnSrCPC}$ may induce overhydroxylation of proline and/or lysine amino acids, potentially accelerating collagen cross-linking and fibre formation, explaining collagen results at $3 \mathrm{DPC}$.

All results obtained in in vitro assays proved that $\mathrm{ZnCPC}$ and $\mathrm{ZnSrCPC}$ cements are able to induce physiologically relevant properties, which may result in enhanced in vivo osteoconductive capacities. Indeed, the first stage for bone formation by osteoblasts is collagen secretion. Type-I collagen is the most abundant type of collagen in bone, being the most abundant protein component in the ECM. Given that CPCs induce Type-I collagen deposition into the ECM and increase the number of the collagen-secreting osteoblastic cells and their differentiation, especially for $\mathrm{ZnSrCPC}$, it was attractive to speculate their good in vivo performance. This was confirmed to be correct in pilot in vivo assays. Cement implants were performed in trabecular bone due to its higher metabolic rate per unit of volume, when compared to cortical bone. Further, rates of change in bone density are likely to be greater at sites that are predominantly trabecular (Dempster et al., 1992) and trabecular bone density decreases faster than that of compact bone as osteoporosis progresses (Seeman et al., 1993). Histological and histomorphometrical analyses of the implants revealed that, with time, new bone regenerated and gradually penetrated into the implant. The pattern of trabecular bone that was being formed in the implanted area was qualitatively similar to the adjacent old trabecular bone in the sections' periphery. New bone grew towards the implant centre, replacing fluorescent-black spaces and suggesting that cement was being first resorbed in the implantation periphery. This is expected, as it is the site of contact between the implant and old bone, mesenchymal cells, and macrophages that ultimately differentiate into osteoclasts. Reduction of the protein-containing organic matrix from 1 to 2 months, along with increased new bone formation to relative high levels (Fig. 6 and 8) also reflected that $\mathrm{ZnCPC}$ and $\mathrm{ZnSrCPC}$ had good osteoconductivities. The cements are potentially good inductors of osteoprogenitor cell proliferation and differentiation, as upon 1 month intensive bone remodelling was undergoing in the implant. Further, results indicated that the presence of $\mathrm{Sr}$ ions, rather than the presence of $\mathrm{Zn}$ ions, greatly inhibits osteoclastic activity, with much fewer osteoclastlike cells being found in $\mathrm{ZnSrCPC}$ implants (Fig. 9a). Partial substitution of $\mathrm{Zn}$ ions by $\mathrm{Sr}$ ions in $\mathrm{ZnSrCPC}$ revealed to be further beneficial, as organized bone formation and most probably cement resorption were faster and higher for this cement (Fig. 8, 11, 12). In contrast, the presence of higher areas of unorganised matrix for $\mathrm{ZnCPC}$ and more so for Norian, (Figs. 2 and 8) indicated that cement and primary matrix were still being resorbed at those zones at 1 month. Of note, the larger solubility of brushite compared to apatite is one essential reason for the faster resorption of the brushite matrix. While apatite cements, such as Norian, remain almost unchanged throughout study periods of 6 months, brushite cements are resorbed at a rate between $60 \%$ and $90 \%$ amid 2-6 
months of study periods (Apelt et al., 2004). In osteogenic terms, for the $\mathrm{ZnCPC}$ cement new bone was mainly found at the periphery of the implant but not at the centre (1 month), while for $\mathrm{ZnSrCPC}, \mathrm{NB}$ was found evenly distributed throughout the implant, with several trabeculaelike structures already crossing the entire histological sections. Upon 2 months, higher levels of bone regeneration could be noted for $\mathrm{ZnCPC}$ and especially for $\mathrm{ZnSrCPC}$, where contiguous trabeculae crossing the histological sections could be found, suggesting the completion of the osteoregenerative process mediated by brushite conversion into apatite.

\section{Conclusions}

High biocompatibility and in vivo performance of brushiteforming $\mathrm{Zn}$ - and $\mathrm{ZnSr}$-substituted $\beta$-TCP cements injected into pig trabecular bone cylindrical defects were observed in a pilot study. Mechanistically, the in vivo performance may rely on the in vitro properties observed for these cements: induction of osteoblastic proliferation, differentiation, adhesiveness, ALP activity, Type-I collagen secretion and deposition into extracellular fibres. All these properties are of crucial relevance in the process of osteoregeneration. In addition, $\mathrm{ZnSrCPC}$ was generally a higher inductor of these osteoblastic properties and, correspondently, presented the best osteoconductive properties. Both $\mathrm{ZnCPC}$ and $\mathrm{ZnSrCPC}$ presented better in vivo performance in comparison to the control carbonated apatite cement (Norian $\mathrm{SRS}^{\circledR}$ ), but the presence of $\mathrm{Sr}$ enhanced the rate of cement resorption and new bone formation. In conclusion, the biological properties observed for the investigated $\mathrm{ZnCPC}$ and $\mathrm{ZnSrCPC}$ cements strongly suggest them as good candidate materials to be used as bone substitutes.

\section{Acknowledgments}

To CICECO and to CBC for the support and to the Portuguese Foundation for Science and Technology for the project REEQ/1023/BIO/2005 and for the fellowship grants of S.P. (SFRH/BPD/64119/2009), S.I.V. (SFRH/ BPD/19515/2004) and P.M.C.T. (SFRH/BD/62021/2009). The authors are also very grateful to Prof. Doutor Henrique Bicha Castelo, Director of the Service of Medicine and Experimental Surgery, Hospital of Santa Maria, Lisbon, for the facilities supply in experimental animal studies, according to European regulations and following permission granted by the Ethical Committee. In addition, the authors are thankful to A. Pinto, Institute of Molecular Medicine, Lisbon, for the preparation of the sections for histological and histomorphometric analysis.

\section{References}

Alves HLR, dos Santos LA, Bergmann CP (2008) Injectability evaluation of tricalcium phosphate bone cement. J Mater Sci - Mater Med 19: 2241-2246.
Apelt D, Theiss F, El-Warrak AO, Zlinszky K, Bettschart-Wolfisberger R, Bohner M, Matter S, Auer JA, Von Rechenberg B (2004) In vivo behavior of three different injectable hydraulic calcium phosphate cements. Biomaterials 25: 1439-1451.

Baroud G, Cayer E, Bohner M (2005) Rheological characterization of concentrated aqueous á-tricalcium phosphate suspensions: The effect of liquid-to-powder ratio, milling time, and additives. Acta Biomater 1: 357363.

Boesel L, Reis RL (2006) The effect of water uptake on the behaviour of hydrophilic cements in confined environments. Biomaterials 27: 5627-5633.

Bohner M, Baroud G (2005) Injectability of calcium phosphate pastes. Biomaterials 26: 1553-1563.

Bohner M, Theiss F, Apelt D, Hirsiger W, Houriet R, Rizzoli G (2003) Compositional changes of a dicalcium phosphate dihydrate cement after implantation in sheep. Biomaterials 24: 3463-3474.

Brown WE, Chow LC (1983) A new calciumphosphate setting cement. J Dent Res 62: 672-672.

Burguera EF, Xu HHK, Sun LM (2008) Injectable calcium phosphate cement: Effects of powder-to-liquid ratio and needle size. J Biomed Mater Res B 84: 493-502.

Constantz BR BB, Ison IC, Fulmer MT, Baker J, McKinney LA, Goodman SB, Gunasekaren S, Delaney DC, Ross J, Poser R (1998) Histological, chemical, and crystallographic analysis of four calcium phosphate cements in different rabbit osseous sites. J Biomed Mater Res Part B 43: 451-461.

Dahl S, Allain P, Marie P, Mauras Y, Boivin G, Ammann $P$ (2001) Incorporation and distribution of strontium in bone. Bone 28: 446-453.

Dempster DW (1992) Bone remodeling. Disorders of bone and mineral metabolism. Raven Press, New York, pp. 355-380.

Fua CY, Dinishb US, Nga BK, Murukeshanb VM, Seahb LK, Lim-Tanc SK (2006) Fluorescence lifetime imaging of haematoxylin and eosin-stained cervical tissue. Proc. Int. Conf. Biomed. Pharm. Eng., Singapore.

Gauthier O, Muller R, von Stechow D, Lamy B, Weiss $\mathrm{P}$, Bouler JM (2005) In vivo bone regeneration with injectable calcium phosphate biomaterial: A threedimensional micro-computed tomographic, biomechanical and SEM study. Biomaterials 26: 5444-5453.

Gisep A, Wieling R, Bohner M, Matter S, Schneider E, Rahn B (2003) Resorption patterns of calciumphosphate cements in bone. J Biomed Mater Res Part A 66: $532-540$.

Ito A, Ojima K, Naito H, Ichinose N, Tateishi T (2000) Preparation, solubility, and cytocompatibility of zincreleasing calcium phosphate ceramics. J Biomed Mater Res 50: 178-183.

Ito A, Kaeamura H, Otsuka M, Ikeuchi M, Ohgushi H, Ishikawa K, Onuma K, Kanzaki N, Sogo Y, Ichinose N (2002) Zinc-releasing calcium phosphate for stimulating bone formation. Mater Sci Eng C 22: 21-25.

Johal KK, Hill RG, Brook IM (2002) In vivo response of strontium and zinc based ionomeric cement implants in bone. J Mater Sci - Mater Med 13: 543-552. 
Kannan S, Pina S, Ferreira JMF (2006) Formation of strontium-stabilized $\alpha$-tricalcium phosphate from calciumdeficient apatite. J Amer Ceram Soc 89: 3277-3280.

Kannan S, Goetz-Neunhoeffer F, Neubauer J, Ferreira JMF (2008) Ionic substitutions in biphasic hydroxyapatite and beta-tricalcium phosphate mixtures: Structural analysis by rietveld refinement. J Amer Ceram Soc 91: 1-12.

Kannan S, Goetz-Neunhoeffer F, Neubauer J, Ferreira JMF (2009) Synthesis and structure refinement of zincdoped beta-tricalcium phosphate powders. J Amer Ceram Soc 92: 1592-1595.

Kawamura H, Ito A, Miyakawa S, Layrolle P, Ojima K, Ichinose N (2000) Stimulatory effect of zinc-releasing calcium phosphate implant on bone formation in rabbit femora. J Biomed Mater Res 50: 184-190.

Kurdy NM, Bowles S, Marsh DR, Davies A, France M (1998) Serology of collagen types I and III in normal healing of tibial shaft fractures. J Orthop Trauma 12: 122126.

Lareu R R, Arsianti I, Harve KS, Peng Y, Raghunath $M$ (2006) In vitro augmentation of collagen matrix formation - Applications in tissue engineering. $3^{\text {rd }}$ Kuala Lumpur Intern Conf Biomed Eng, 15. (DOI 10.1007/9783-540-68017-8).

Lecoeur L, Ouhayoun JP (1997) In vitro induction of osteogenic differentiation from non-osteogenic mesenchymal cells. Biomaterials 18: 989-993.

Lenart G, Bidlo G, Pinter J (1972) Some basic problems in examination of calcium hydrogen phosphates of bone. Clinical Orthop Rel Res 83: 263-272.

Li X, Sogo Y, Ito A, Mutsuzaki H, Ochiai N, Kobayashi $\mathrm{T}$ (2009) The optimum zinc content in set calcium phosphate cement for promoting bone formation in vivo. Mater Sci and Eng C 29: 969-975.

Malik M, Puleo D, Bizios R, Doremus R (1992) Osteoblasts on hydroxyapatite, alumina and bone surfaces in vitro: morphology during the first 2 hours of attachment. Biomaterials 13: 123-128.

Marie P, Ammann P, Boivin G, Rey C (2001) Mechanisms of action and therapeutic potential of strontium in bone. Calcif Tissue Int 69: 121-129.

McComb R, Bowers G, Posen S. Alkaline Phosphatase. Plenum, New York, 1979.

Naji A, Harmand M (1991) Cytocompatibility of two coating materials, amorphous alumina and silicon carbide, using human differentiated cell cultures. Biomaterials 12: 690-694.

Nelson DL, Cox MM (2005) Lehninger's Principles of Biochemistry. W.H. Freeman, New York, NY.

Otsuka M, Marunaka S, Matsuda Y, Ito A, Layrolle P, Naito H (2000) Calcium level-responsive in vitro zinc release from zinc containing tricalcium phosphate (ZnTCP). J Biomed Mater Res 52: 819-824.

Otsuka M, Ohshita Y, Marunaka S, Matsuda Y, Ito A, Ichinose N, Otsuka K, Higuchi WI (2004) Effect of controlled zinc release on bone mineral density from injectable $\mathrm{Zn}$-containing beta-tricalcium phosphate suspension in zinc-deficient diseased rats. J Biomed Mater Res A 69: 552-560.

Owen TA, Aronow M, Shalhoub V, Barone LM, Wilming L, Tassinari MS (1990) Progressive development of the rat osteoblast phenotype in vitro: reciprocal relationships in expression of genes associated with osteoblast proliferation and differentiation during formation of the bone extracellular matrix. J Cell Phys 143: 420-430.

Pina S, Torres PMC, Goetz-Neunhoffer F, Neubauer J, Ferreira JMF (2010a) Newly developed Sr-substituted a-TCP bone cements. Acta Biomaterialia 6: 928-935 (doi: 10.1016/j.actbio.2009.09.001).

Pina S, Vieira SI, Torres PMC, Goetz-Neunhoeffer F, Neubauer J, da Cruz e Silva OAB, da Cruz e Silva EF, Ferreira JMF (2010b) In vitro performance assessment of new brushite-forming $\mathrm{Zn}$ - and $\mathrm{ZnSr}$-substituted b-TCP bone cements. J Biomed Mater Res B, in press.

Puleo D, Preston K, Shaffer J, Bizios R (1993) Examination of osteoblast-orthopaedic biomaterial interactions using molecular techniques. Biomaterials 14: 111-114.

Rokita E, Hermes C, Nolting HF, Ryczek J (1993) Substitution of calcium by strontium within selected calcium phosphates. J Crystal Growth 130: 543-552.

Seeman E, Young N, Szmukler G, Tsalamandris C, Hopper JL (1993) Risk-factors for osteoporosis. Osteoporosis Int 3: S40-S43.

Stein GS, Lian JB, Gerstenfeld LG, Shalhoub V, Aronow M, Owen TA (1989) The onset and progression of osteoblast differentiation is functionally related to cellular proliferation. Connect Tissue Res 20: 3-13.

Sweeney S, Orgel J, Fertala A, McAuliffe JD, Turner KR, Di Lullo GA, Chen S, Perumal S, Ala-Kokko L, Forlino A, Cabral WA, Barnes AM, Marini JC, San Antonio JD (2008) Candidate cell and matrix interaction domains on the collagen fibril, the predominant protein of vertebrates. J Biol Chem 283: 21187-21197.

Ueno A, Miwa Y, Miyoshi K, Horiguchi T, Inoue H, Ruspita I (2006) Constitutive expression of thrombospondin 1 in MC3T3-E1 osteoblastic cells inhibits mineralization. J Cell Phys 209: 322-332.

Wang XP, Ye JD, Wang H (2006) Effects of additives on the rheological properties and injectability of a calcium phosphate bone substitute material. J Biomed Mater Res B 78: 259-264.

Wen HB, Cui FZ, Feng QL, Li HD, Zhu XD (1995) Microstructural investigation of the early external callus after diaphyseal fractures of human long-bone. J Struct Biol 114: 115-122.

Yuan HP, Li YB, de Bruijn JD, de Groot K, Zhang XD (2000) Tissue responses of calcium phosphate cement: a study in dogs. Biomaterials 21: 1283-1290.

\section{Discussion with Reviewers}

Reviewer I: Is the positive effect of the incorporation of $\mathrm{Zn}$ and $\mathrm{Sr}$ ions into brushite cements due to the release of $\mathrm{Zn}$ and $\mathrm{Sr}$ ions or due to a different reason such as a change of surface roughness or a change of $\mathrm{Ca}$ or phosphate ion release?

Authors: Based on our previous study (Pina et al., 2010b, text reference), $\mathrm{ZnCPC}$ and $\mathrm{ZnSrCPC}$ cements were able to release, into the simulated body fluid (SBF) solution, 
the relevant (from the physiological view point) $\mathrm{Zn}$ and Sr ions and to transform into apatite under that conditions. Therefore we think that the positive effect of the incorporation of $\mathrm{Zn}$ and $\mathrm{Sr}$ ions into brushite cements is related with the release of $\mathrm{Zn}$ and $\mathrm{Sr}$ ions into the physiological fluid.

Reviewer II: What was the rationale for using the particular substitution levels?

Authors: The available literature reports on the effect of ionic substitution levels on in vitro and in vivo tests are scarce. In our previous works dealing with substitution of $\mathrm{Zn}$ and $\mathrm{Sr}$ ions in the structure of calcium phosphates we have covered a broad range of compositions. The levels selected in the present work are intermediate values and the aim was to evaluate their effects on the response of bone cements in vitro and in vivo.

Reviewer III: Regarding the in vitro experiments, please discuss why you chose to test the behaviour of cells by applying cement-conditioned medium, instead of cement itself. Also, it is mentioned that for cytotoxicity experiments, cement powder was added to the well plates with cells. This needs clarification. Was the cement itself (i.e., cement set upon mixing of powder and liquid phase) used, or only the powder fraction of the cement. If the former is the case, please explain how the particles were made, and what their size was. If the latter is the case, then the rationale behind this choice needs to be explained.

Authors: Concerning the in vitro studies, we chose to test the behaviour of cells by applying powdered set cements to conditioned medium mainly due to the higher surface area of contact between the biomaterials and cells and conditioned medium when using powder formulation, when comparing with cement in blocks. Additionally, we have previously observed in preliminary experiments that pre-osteoblastic MC3T3 cells adhere better to powders than to cements in blocks. The cytotoxicity tests were performed with powdered cement, i.e.,cement set upon mixing of powder and liquid, followed by milling. The powder had an average particle size of about $15 \mu \mathrm{m}$.

Reviewer III: A similar question goes for the ALP activity. Why were the experiments performed on powders and not on set cement?
Authors: The same rationale as for the proliferation studies was applied here, and the experimental design was maintained throughout the in vitro analyses for the sake of consistency.

Reviewer III: Regarding the cell adhesion test, what is the meaning of the adhesiveness of cells to plastic in the presence or absence of cement? Adhesiveness to cements seems a more relevant analysis. Please comment!

Authors: Observations of altered cell adhesiveness to the plastic in the ALP assays prompted us to analyse this issue. Hence, we tested if cells gained more capacity to adhere to an extracellular support when previously cultivated in the presence of cements. Cell adherence to an extracellular support (as the plastic plate) or matrix requires a series of transmembrane proteins (cell adhesion molecules such as integrins and glycoproteins) generally involved in cell-tocell and cell-to-matrix adhesion. The data obtained are relevant for the ability of cells to adhere to organic structures such as other cells, extracellular protein matrix, and new bone, which can accelerate the remodelling process. It would indeed also be relevant to analyse cell adhesiveness to cements, although it is more difficult to directly quantify cells adherent to the powders (e.g., cell collection and counting) accurately.

Reviewer III: In the Discussion it is stated that the two cements induced cellular proliferation. How was the induction proven?

Authors: The cellular toxicity/proliferation assay proves that for certain cements concentrations the number of cells increases with time over control cells. This was denoted from the Resazurin assay (Fig. 3) and also when counting cells for the set up of the adhesion assay (data not shown). This is a strong indicator of increased cell proliferation, and a higher number of cells was indeed observed in the corresponding phase contrast microphotographs. It could also result from increased cellular survival, but typically this does not render the fold-increases obtained e.g., for $1.0 \mathrm{mg} / \mathrm{mL} \mathrm{ZnSrCPC}$ (Fig. 3b). Indeed, the percentage of non-viable (compromised) cells in the MC3T3 control population is typically no more than $5 \%$ (as we previously observed when counting cells for a growth curve (Pina et al., 2010b) and when counting cells for the adhesion assay of Fig. 5). 